\title{
Árpád Kovács
}

\section{The Career of Rule Based Budgeting in Hungary ${ }^{1}$ The Success of an European Solution in Fiscal Stability, Sustainable Development and in Improving Efficiency}

\section{Summary}

Starting from the macro processes of the national economy and public finances the article examines three economic-public finance turnarounds in Hungary: the improvement of financial stability, the sustainability of the outstanding economic growth and the improvement of efficiency to be achieved and in all of this the role of rule-based budgeting. It shall introduce the regulatory and institutional solutions of the latter i.e. how this service, as a logical consequence of a framework, became a useful part of the financial policy by implementing its rules and - as an annual realisation of the above - a useful part of the budgeting practice. The article reaches the conclusion that it was unavoidable to "elevate" the major stipulations of the rule-based budgeting and the rules of the guarantee-like operation of the institution guarding over the implementation of these rules in the Fundamental Law of Hungary in 2011 to thus strengthen budgetary responsibility. Additionally, the article is dealing with the relations of the Hungarian and EU regulations, the main characteristic features of the work of the Fiscal Council, the FC's recommendations made during the past nine years and the effects of the said recommendations.

Journal of Economc Literature (JEL) codes: B15, E62, H15, H61, H63, L38, P48 Keywords: fiscal policy, crisis management, debt management fiscal stability

ÁRPÁD KovÁcs, Professor, University of Szeged, Chairman of the Fiscal Council and Honorary Chairman of the Hungarian Economic Association (kovacsa1948@ gmail.com). 


\section{Árpád Kovács: The Career of Rule Based Budgeting in Hungary}

INTRODUCTION, THE ESSENCE OF RULE-BASED BUDGETING

The approach to the development of economic history is related to "theories" (Sombart, 1929). However, to the majority of the social-economic actors it is not theory, rather the actually used instruments and, primarily, the result itself is important. And the latter can be captured mostly in the sustainability of the social-economic functioning, the stability and the services provided by public finance. Thus the truth of the motto ${ }^{2}$ of the Parliamentary Budget Officials (PBO-s) and of the Independent Fiscal Institutions (IFI-s): Better budget - Better life is hardly disputable. As regards their essence the direct social values and interests directly related to public finance can be associated with the quality, expansion and availability of services - with better life - and, indirectly with its basic condition, financial stability - with better budget. It is common knowledge that the pre-condition of the realisation of the target system of fiscal policy is the continued position of the budget (public finance) close to balance, the funding of social services respectively, keeping the degree of state re-distribution on a level required for reaching the above goals. Their role is decisive not only from the aspect of decreasing government debt but also from the aspect of the competitiveness of the whole of the national economy. Ultimately the sustainability of the social-economic development depends on these factors (Kovács, 2019).

In the course of the past decades budgetary slippages and, as a consequence, problems of sustainability and growing indebtedness - accompanied by bank crises too appeared not only in the emerging countries but also in a line of developed countries (Antal, 2004; Bod, 2013; Muraközy, 2010; Kovács O., 2013). ${ }^{3}$

Lack of financial stability can paralyse the social-economic functioning of a country already within a few years. That's why regaining and maintaining financial stability has become such an important strategic issue all over the world that demanded new solutions - regulations and institutions. The so-called rule-based budgeting fits into this framework of fiscal policy (Kutasi, 2012). Implementing this has spread first in the economic crisis ridden countries of Latin America then, from the 80s, all over the worlds, thus also in Europe. Each member states of the European Union, thus Hungary as well, are following these set of rules - naturally with smaller or bigger departures, but alongside tangible principles - in their respective fiscal policies. The socalled "rule-based fiscal policy" means more than merely following the rules governing the preparation and execution of the budget as it dictates the framework of budgetary responsibility via the rules of budgetary-political, procedural-transparency regulations as well as via the institutional mechanism of the institutions set up to guarantee the observance of these rules (Kutasi, 2012). The system used in the practice is consisting of these rules and mechanisms -observing naturally the peculiarities of the given country (Ódor, 2014).

From the middle of the first decade of the 2000s it became clear also in Hungary that the more disciplined realisation of the current budget was far from enough to prevent the slippages of the budget that broke away from the performance. That's why regaining and maintaining the financial stability of the Hungarian public financ- 
es that was close to national bankruptcy, became such a strategic issue that called for a new, constitutional stipulations and high level legal norms built on those stipulations that uniformly regulated public finances. The domestic endeavours, following international examples to stop public finance over-expenditures and set solid foundations for the finances of the country served this purpose successfully, followed in 2011 by the regulations stipulated by the Fundamental Law of Hungary ${ }^{4}$ and in the Stability $\mathrm{Act}^{5}$. Before describing in detail the Hungarian solutions, the domestic practice of rule-based budgeting, we should briefly mention the international career of the regulatory and institutional system that has been often referred to as a "magic fiscal weapon".

\section{SKETCHY INTERNATIONAL OUTLOOK}

\section{Principles of rule-based budgeting practice as a therapy}

Rule-based budgeting and the financing built on this principle imply the better harmony of resources and are undoubtedly mitigating the cyclical nature of budgeting (Kopits, 2013). The lessons of the crisis have completed this "classic function" by the fact that introducing rule-based fiscal policy could be a tool of crisis management (Reinhart and Rogoff, 2010; Kovács, Á., 2013).

Governments of several countries opted for the introduction of rule-based budgeting hoping that with the assistance of this method the balance tensions will be contained and conditions of lasting funding, growth and sustainable development can be created. To this end they laid down in law, even in constitutional stipulations - in the form of numeric rules, planned according to a specific rule of procedure and supervising them institutionally - the revenue and expenditure proportions of the budget and the acceptable degree of the indebtedness (Kopits, 2013).

In our practice all this meant that

- fiscal policy regulations are being used (for example, expenditure limits to maintain the budgetary balance),

- fiscal procedural regulations were introduced (for example, medium term fiscal planning, the obligatory compensation of expenditures),

- enforced transparency norms (for example, accrual based accounting, reporting system),

- established institutional guarantees to enforce transparency and the observance of regulations respectively, the "supervision" of the macro and micro economy (for example, apart from the SAI of the country - or within its organisation - operating a parliamentary institution and/or fiscal council that is independent from the government and empowered by the right to express an opinion on the central budget).

Naturally, there are essential differences depending on how rapid and deep the worsening of the national economy and financial conditions were and to what extend the new circumstances have become pressing and calling for instant action. Apart from the abilities of the existing financial system and its flexibility as regards modernisation and absorption, it was the above that essentially determined the contents, the 
tempo of its introduction as well as the circumstances of its functioning, the authorisations of the institution guarding over the observance of the rules and the entitlement of the institution within the public authorities. Apart from the limiting factors as regards the implementation of the system that were also related to the differences of the national public finances systems, the international experiences also indicated that by the consistent operation of the system the trend that was apparent in the past decades both in the emerging and the developed countries and was embodied by budgetary over-expenditure, the un-sustainability of the budget and the growing sovereign debt could be reversed (Orbán and Szapáry, 2006).

\section{Solutions to be found in international practice}

The practice of rule based budget thus started from South America but by today more than 50 countries in the world are employing such solutions with more or less consistency and a rather varied status of "supervisory" organisations, bodies. We should add that the dominant employment of such a framework, serving the purpose of financial stability that - classified according to their specific, common characteristic features, their functioning norms and attempts to build an institutional cooperation - are typical for the countries of the European Union and, as of 2015, the fiscal functioning of the Commission of the European Union. ${ }^{6}$ We can find more than half of such fiscal policy, procedural and institutional solutions within the European Union. That's why we can talk about a "European" solution that proved to be successful in maintaining financial matters - referring to the title of the present article. Namely, thanks to its main characteristics, operational characteristic features and by establishing financial stability, the Hungarian practice falls in this category as well.

Here we mention that the Maastricht system of criteria of the European Union itself is working as a specific network. We can regard its requirements as "numerical and procedural regulations" employed as a compulsory and uniformed system of rules. Let's just think about the 3 percent deficit limit - compared to the gross domestic product (GDP), or the target of the GDP proportionate government debt set in $60 \%$, in case of the latter stipulation, the rule that the debt exceeding this limit shall have to be decreased annually by $1 / 20$ th part, or the European Fiscal Board established as an advisory body in 2015 for the member countries of the euro area, that is an independent fiscal institution of the European Commission.

Some European countries have introduced it well before the 2008 crisis and have established Independent Fiscal Institutions (IFIs) i.e. fiscal institutions independent from the government and bearing budgetary responsibility.

As it's apparent from Table 1, elements of the rule-based budgeting were used in a variety of ways. It's the requirements of maintaining balance that are predominant however, we can find more concrete stipulations, like limiting expenditures, deficit and indebtedness (ceiling) as well as calling for medium term planning. Loss of reputation, as a consequence of sanctions applied by fiscal institutions is common. In case of Poland we can see the option of legal sanctioning - for example, the possibility of 
re-discussing the budget - while financial sanctioning - for example, the suspension of EU resources - is applicable in the countries of the euro area (Franco, 2011).

The method of creating fiscal institutions was differed. Mostly it happened by a law adopted by simple parliamentary majority or political guideline (agreement), respectively by constitutional regulation.

Table 1: Functions and competence of the independent fiscal institutions guarding over the compliance with the budget in the individual EU Member States prior to the 2008 financial crisis

\begin{tabular}{|c|c|c|c|c|c|c|c|c|c|}
\hline & Country & DK & $\mathbf{B E}$ & LV & SE & BG & $\mathbf{E E}$ & PL & UK \\
\hline & $\begin{array}{l}\text { Date of introducing the Fiscal } \\
\text { Rule }\end{array}$ & 1962 & 1989 & 1990 & $\begin{array}{l}1997-98 \\
2007\end{array}$ & 1998 & 1998 & 1998 & 1998 \\
\hline \multirow{11}{*}{ 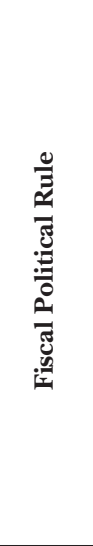 } & Deficit Limit & & & & & $\mathrm{X}$ & & & \\
\hline & Structural Surplus or Deficit & & $\mathrm{X}$ & & $\mathrm{X}$ & & & & \\
\hline & Limit of Expenditures & & $\mathrm{X}$ & & $\mathrm{X}$ & & & & \\
\hline & Limit of Total Expenditures & & & & & & & & \\
\hline & Current Balance & & & & & & & & $\mathrm{X}$ \\
\hline & General Balance & $\mathrm{X}$ & $\mathrm{X}$ & $\mathrm{X}$ & & & $\mathrm{X}$ & & \\
\hline & Efficiency Investigations & & & & & & & & \\
\hline & Medium Term Planning & $\mathrm{X}$ & & & & & & & $\mathrm{X}$ \\
\hline & Debt Limit & & & & & & & $\mathrm{X}$ & $\mathrm{X}$ \\
\hline & Sustainability & & & & & & & & \\
\hline & Stability Fund & & & & & $\mathrm{X}$ & $\mathrm{X}$ & & \\
\hline \multirow{3}{*}{ 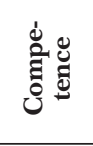 } & Public Finance & $\mathrm{X}$ & $\mathrm{X}$ & $\mathrm{X}$ & $\mathrm{X}$ & $\mathrm{X}$ & $\mathrm{X}$ & $\mathrm{X}$ & $\mathrm{X}$ \\
\hline & National (Central, Federal) & & $\mathrm{X}$ & & & & & & \\
\hline & Subnational governments & & $\mathrm{X}$ & & & & & $\mathrm{X}$ & \\
\hline \multirow{4}{*}{ 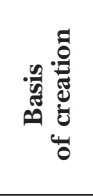 } & Constitution & & & & & & & $\mathrm{X}$ & \\
\hline & Law & $\mathrm{X}$ & $\mathrm{X}$ & $\mathrm{X}$ & $\mathrm{X}$ & & & & \\
\hline & International Agreement & & & & & & & & \\
\hline & Political Guideline, Agreement & & & & $\mathrm{X}$ & $\mathrm{X}$ & $\mathrm{X}$ & & $\mathrm{X}$ \\
\hline \multirow{2}{*}{ 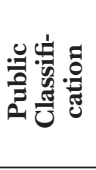 } & $\begin{array}{l}\text { Independent, Parliamentary } \\
\text { Organisation }\end{array}$ & $\mathrm{X}$ & $\mathrm{X}$ & $\mathrm{X}$ & $\mathrm{X}$ & $\mathrm{X}$ & $\mathrm{X}$ & & $\mathrm{X}$ \\
\hline & $\begin{array}{l}\text { Belonging to the Executive } \\
\text { Branch }\end{array}$ & & & & & & & $\mathrm{X}$ & \\
\hline \multirow{4}{*}{ 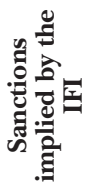 } & Right to Veto & & & & & & & & \\
\hline & Loss of Reputation & $\mathrm{X}$ & $\mathrm{X}$ & $\mathrm{X}$ & $\mathrm{X}$ & $\mathrm{X}$ & $\mathrm{X}$ & $\mathrm{X}$ & $\mathrm{X}$ \\
\hline & Legal & & & & & & & $\mathrm{X}$ & \\
\hline & Financial & & & & & & & & \\
\hline
\end{tabular}

Note: The abbreviation of the individual countries according to internationally used abbreviations.

Source: European Commission, 2012b; FC homepages 
Table 2: Functions and competence of the independent fiscal institutions guarding over the compliance with the budget in the individual EU Member States in the EU Countries on 31st December 2019

\begin{tabular}{|c|c|c|c|c|c|c|c|c|c|c|c|c|c|}
\hline & Country & NL & $\mathbf{B E}$ & LU & LV & LT & SE & UK & BG & $\mathbf{E E}$ & PL* & ES & HU \\
\hline & $\begin{array}{l}\text { Date of the Introduction } \\
\text { of the Fiscal Rule }\end{array}$ & 1945 & 1989 & 1990 & 1990 & 1997 & $\begin{array}{c}1997-98, \\
2007\end{array}$ & $\begin{array}{l}1998, \\
2010\end{array}$ & 1998 & 1998 & 1998 & 2001 & 2009 \\
\hline \multirow{11}{*}{ 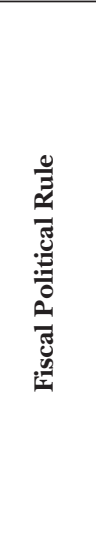 } & Deficit Limit & & & & & & & & $\mathrm{X}$ & & & & $\mathrm{X}$ \\
\hline & Stability Fund & & & & & & & & $\mathrm{X}$ & $\mathrm{X}$ & & & \\
\hline & Structural Surplus & & & & & & $\mathrm{X}$ & & & & & & \\
\hline & $\begin{array}{l}\text { Primary Expenditure } \\
\text { Limit }\end{array}$ & & $\mathrm{X}$ & & & & $\mathrm{X}$ & & & & & $\mathrm{X}$ & \\
\hline & Total Expenditure Limit & & & $\mathrm{X}$ & & & & & $\mathrm{X}$ & & & & \\
\hline & Current Balance & & & & & & & $\mathrm{X}$ & & & & & \\
\hline & General Balance & $\mathrm{X}$ & $\mathrm{X}$ & $\mathrm{X}$ & $\mathrm{X}$ & $\mathrm{X}$ & & & & $\mathrm{X}$ & $\mathrm{X}$ & $\mathrm{X}$ & \\
\hline & Efficiency Investigation & $\mathrm{X}$ & & & & & & & & & & & \\
\hline & Medium Term Planning & $\mathrm{X}$ & & & & & & $\mathrm{X}$ & & & & & $\mathrm{X}$ \\
\hline & Debt Limit & $\mathrm{X}$ & & $\mathrm{X}$ & & $\mathrm{X}$ & & $\mathrm{X}$ & & & $\mathrm{X}$ & $\mathrm{X}$ & $\mathrm{X}$ \\
\hline & Sutainability & & & & & & & & & & & & \\
\hline \multirow{3}{*}{ 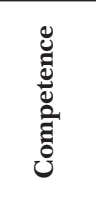 } & Public Finance & $\mathrm{X}$ & $\mathrm{X}$ & $\mathrm{X}$ & $\mathrm{X}$ & $\mathrm{X}$ & $\mathrm{X}$ & $\mathrm{X}$ & $\mathrm{X}$ & $\mathrm{X}$ & $\mathrm{X}$ & $\mathrm{X}$ & $\mathrm{X}$ \\
\hline & $\begin{array}{l}\text { National (Central, } \\
\text { Federal) }\end{array}$ & $\mathrm{X}$ & & & & & $\mathrm{X}$ & & & & & $\mathrm{X}$ & $\mathrm{X}$ \\
\hline & $\begin{array}{l}\text { Sub-national Govern- } \\
\text { ment }\end{array}$ & $\mathrm{X}$ & $\mathrm{X}$ & & & & & & & & $\mathrm{X}$ & $\mathrm{X}$ & \\
\hline \multirow{4}{*}{ 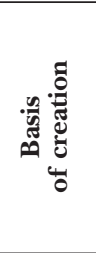 } & Constitution & & & & $\mathrm{X}$ & $\mathrm{X}$ & & & & & $\mathrm{X}$ & & $\mathrm{X}$ \\
\hline & Law & $\mathrm{X}$ & $\mathrm{X}$ & & & $\mathrm{X}$ & $\mathrm{X}$ & $\mathrm{X}$ & $\mathrm{X}$ & $\mathrm{X}$ & & $\mathrm{X}$ & $\mathrm{X}$ \\
\hline & $\begin{array}{l}\text { International Agree- } \\
\text { ment }\end{array}$ & & & & & & & & & & & & \\
\hline & $\begin{array}{l}\text { Political Guideline, } \\
\text { Agreement }\end{array}$ & & $\mathrm{X}$ & $\mathrm{X}$ & & & & & & & & & \\
\hline \multirow{2}{*}{ 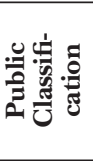 } & $\begin{array}{l}\text { Independent, Parlai- } \\
\text { mentary Organisation }\end{array}$ & $\mathrm{X}$ & $\mathrm{X}$ & $\mathrm{X}$ & $\mathrm{X}$ & $\mathrm{X}$ & $\mathrm{X}$ & $\mathrm{X}$ & $\mathrm{X}$ & $\mathrm{X}$ & & $\mathrm{X}$ & $\mathrm{X}$ \\
\hline & $\begin{array}{l}\text { Belonging to the Execu- } \\
\text { tive Branch }\end{array}$ & & & & & & & & & & $\mathrm{X}$ & & \\
\hline \multirow{4}{*}{ 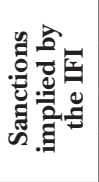 } & Right to Veto & & & & & & & & & & & & $\mathrm{X}$ \\
\hline & Loss of Reputation & $\mathrm{X}$ & $\mathrm{X}$ & $\mathrm{X}$ & $\mathrm{X}$ & $\mathrm{X}$ & $\mathrm{X}$ & $\mathrm{X}$ & $\mathrm{X}$ & $\mathrm{X}$ & $\mathrm{X}$ & $\mathrm{X}$ & $\mathrm{X}$ \\
\hline & Legal & & $\mathrm{X}$ & & $\mathrm{X}$ & $\mathrm{X}$ & & & & $\mathrm{X}$ & $\mathrm{X}$ & & $\mathrm{X}$ \\
\hline & Financial & & & & & & & & & & & & \\
\hline
\end{tabular}

Note: The abbreviation of the individual countries according to internationally used abbreviations.

* In Austria there are two institutions functioning: Fiscalrat (Fiscal Council) using the technical background of the Central Bank of Austria and Budgetdienst (the Fiscal Institution of the Austrian Parliament). ** By inviting the IFI of Poland that is functioning as a governmental institutions OECD essentially "adopted" it in the group of the IFI institutions.

Source: European Commission, 2012b; FC websites 
Civic Review · Vol. 15, Special Issue, 2019

\begin{tabular}{|c|c|c|c|c|c|c|c|c|c|c|c|c|c|c|c|c|}
\hline SI & FI & DK & RO & DE & IE & GR & HR & $\mathbf{A T}^{* * *}$ & IT & SK & PT & FR & MT & $\mathbf{C Y}$ & EA & CZ \\
\hline \multirow[t]{6}{*}{2009} & 2010 & 2010 & 2010 & 2010 & 2011 & 2011 & 2011 & 2012 & 2012 & 2012 & 2012 & 2013 & 2014 & 2014 & 2015 & 2017 \\
\hline & & & & $\mathrm{X}$ & $\mathrm{X}$ & & & $\mathrm{X}$ & & & $\mathrm{X}$ & & & & $\mathrm{X}$ & \\
\hline & & & & & & $\mathrm{X}$ & & & & & & & & & & \\
\hline & & & & & & & & & & & & & & & & \\
\hline & & & & & & & & & & & & $\mathrm{X}$ & & & & \\
\hline & & & & $\mathrm{X}$ & & & & & & & & & & & & \\
\hline $\mathrm{X}$ & $\mathrm{X}$ & $\mathrm{X}$ & $\mathrm{X}$ & $\mathrm{X}$ & $\mathrm{X}$ & $\mathrm{X}$ & $\mathrm{X}$ & $\mathrm{X}$ & $\mathrm{X}$ & $\mathrm{X}$ & $\mathrm{X}$ & $\mathrm{X}$ & $\mathrm{X}$ & $\mathrm{X}$ & $\mathrm{X}$ & $\mathrm{X}$ \\
\hline & & & & & & & & & & & & & & & & \\
\hline X & X & X & X & & & X & & $\mathrm{X}$ & & & & X & & & & \\
\hline$X$ & $\mathrm{X}$ & & $\mathrm{X}$ & & & & & $\mathrm{X}$ & & $\mathrm{X}$ & & & & $\mathrm{X}$ & $\mathrm{X}$ & $\mathrm{X}$ \\
\hline $\mathrm{X}$ & & & & & & & & $\mathrm{X}$ & $\mathrm{X}$ & & & & & & & $\mathrm{X}$ \\
\hline \multirow[t]{4}{*}{$\mathrm{X}$} & $\mathrm{X}$ & $\mathrm{X}$ & $\mathrm{X}$ & $\mathrm{X}$ & $\mathrm{X}$ & $\mathrm{X}$ & $\mathrm{X}$ & $\mathrm{X}$ & $\mathrm{X}$ & $\mathrm{X}$ & $\mathrm{X}$ & $\mathrm{X}$ & $\mathrm{X}$ & $\mathrm{X}$ & $\mathrm{X}$ & $\mathrm{X}$ \\
\hline & $\mathrm{X}$ & & & $\mathrm{X}$ & & $X$ & & & & & & $\mathrm{X}$ & & & $\mathrm{X}$ & \\
\hline & & & & $\mathrm{X}$ & & & & $\mathrm{X}$ & & & $\mathrm{X}$ & & & & & \\
\hline & & $\mathrm{X}$ & & $\mathrm{X}$ & & & & & $\mathrm{X}$ & $\mathrm{X}$ & & $\mathrm{X}$ & $X$ & & & \\
\hline \multirow[t]{3}{*}{$X$} & $\mathrm{X}$ & & $\mathrm{X}$ & & $\mathrm{X}$ & $\mathrm{X}$ & & $\mathrm{X}$ & & $\mathrm{X}$ & $\mathrm{X}$ & $\mathrm{X}$ & & $\mathrm{X}$ & & $\mathrm{X}$ \\
\hline & & & & & & & & & & & & & & & $\mathrm{X}$ & \\
\hline & $\mathrm{X}$ & & & $\mathrm{X}$ & & & $\mathrm{X}$ & & & & & & & & & \\
\hline \multirow[t]{3}{*}{$X$} & $\mathrm{X}$ & $\mathrm{X}$ & $\mathrm{X}$ & $\mathrm{X}$ & $\mathrm{X}$ & $\mathrm{X}$ & $\mathrm{X}$ & $\mathrm{X}$ & $\mathrm{X}$ & $\mathrm{X}$ & $\mathrm{X}$ & $\mathrm{X}$ & $X$ & $\mathrm{X}$ & $\mathrm{X}$ & $\mathrm{X}$ \\
\hline & & & & & & & & & & & & & & & & \\
\hline & & & & & & & & & & & & & & & & \\
\hline \multirow[t]{3}{*}{$\mathrm{X}$} & $\mathrm{X}$ & $\mathrm{X}$ & $\mathrm{X}$ & $\mathrm{X}$ & $\mathrm{X}$ & $\mathrm{X}$ & $\mathrm{X}$ & $\mathrm{X}$ & $\mathrm{X}$ & $\mathrm{X}$ & $\mathrm{X}$ & $\mathrm{X}$ & $\mathrm{X}$ & $\mathrm{X}$ & & $\mathrm{X}$ \\
\hline & & $\mathrm{X}$ & $\mathrm{X}$ & $X$ & & $\mathrm{X}$ & & $\mathrm{X}$ & & $\mathrm{X}$ & $\mathrm{X}$ & $\mathrm{X}$ & $\mathrm{X}$ & & & \\
\hline & & & & & & & & & & & & & & & $\mathrm{X}$ & \\
\hline
\end{tabular}


In the European practice institutions safeguarding the observance of rules - the fiscal councils - are partly or completely separated from governments and are independent from the governments and their independence is protected by constitutional guarantees, even from the internal organisations of the parliaments (congress, national assembly) that have a role to support and assist the preparation of the budget (the budget offices of the parliaments) that the international terminology is referring to as Budget Office/s (BPO). As we are going to address this issue later the independent fiscal institutions have various opportunities to enforce their opinions and have public law mandates of different strength.

In the public law classification of organisations guarding over the compliance of the regulations, independence from the government was generally applicable however, we see Poland as the "odd one out" where it was established ten years prior to the crisis, as part of the executive branch. ${ }^{7}$ Table 2 shows that among the countries accessing the European Union lately that the number of countries employing such budgetary stipulations and institutional guarantees has significantly grown in the period following the crisis, ${ }^{8}$ due to the developing integration and the example of those countries that having followed the practice of rule-based budgeting successfully managed the crisis (Kovács Á., 2013).

From the 13 countries having accessed the EU following 2004 rule-based budgeting is the rule and the compliance is guaranteed by independent institutions. In 5 countries the system was launched before the outbreak of the 2008 crisis, while in seven countries - among them in Hungary - it was introduced in the period 20092014. In the 13th country - in the Czech Republic - the fiscal council was established in 2017. ${ }^{9}$

The institutional operation alongside the general principles mentioned under point 2.1 offers an opportunity for the cooperation of national institutions. ${ }^{10}$ The predominance of identities is a characteristic feature however, as regards the utilisation of the budget elements in the practice as well as the responsibilities, competence and authorisation the picture is more varied. ${ }^{11}$

Let us finish this considerably sketchy international outlook with the question whether with the introduction of fiscal regulations and institutions (fiscal councils) has financial management became more disciplined in the fiscal sector? It is a fact that opting for the introduction of a stricter regime has followed the road of mitigation (see Chart 1) in the majority of the countries. Although some countries of Southern Europe that are EU members are running their respective financial system by a specific "compulsory solidarity", the practice of rule-based budgeting produced certain results nevertheless.

The change is even more plastic if we examine separately the sovereign debt data of the so-called Visegrád Group countries ${ }^{12}$ (see Chart 2). Following the 2008 crisis these countries witnessed the start of an economic growth that was nearly three times bigger that the EU average.

In these countries it could become an objective that the new fiscal policy should serve also the strengthening of efficiency in the social-economic operation, beyond 
Chart 1: The Gross National Product (GDP) proportionate sovereign debt of some of the European Union countries and the date of the establishing of their independent fiscal institutions

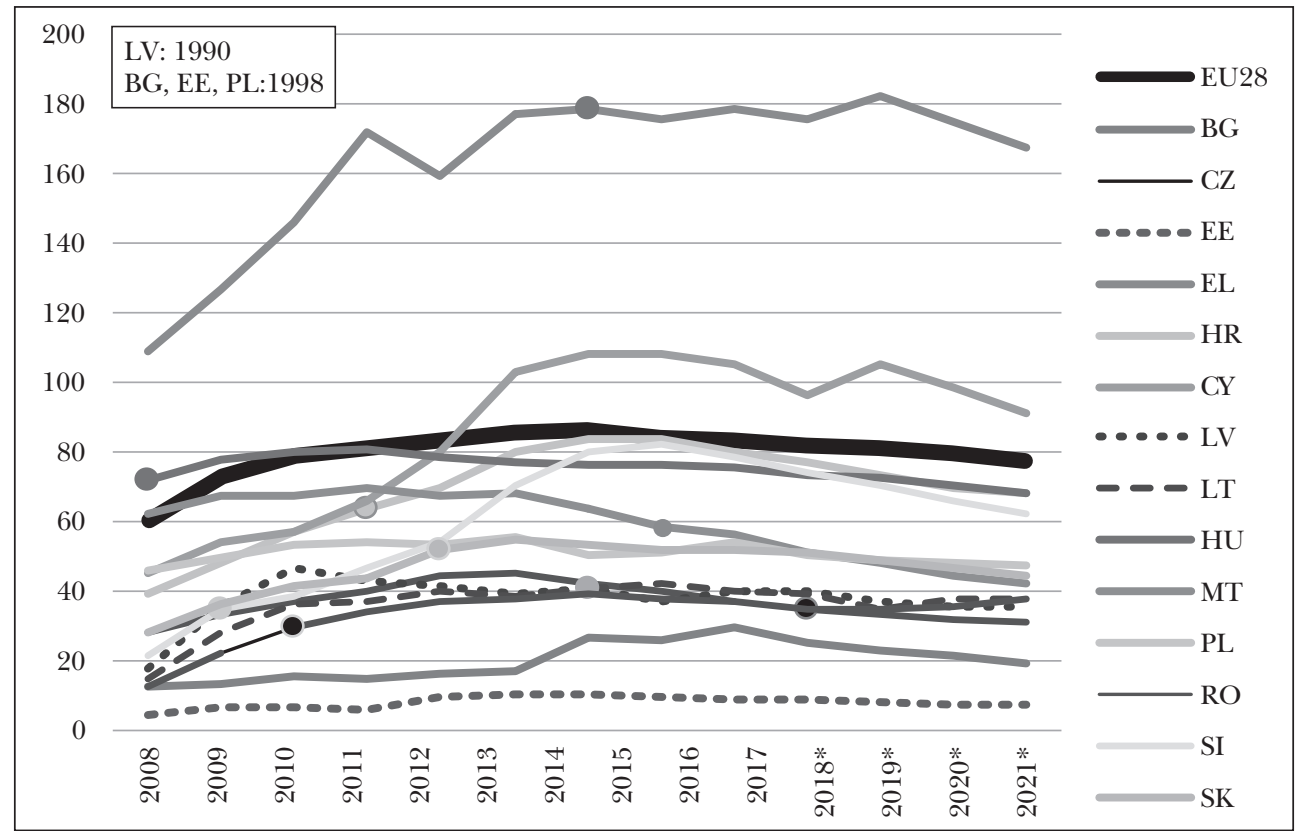

Source: Eurostat, 2019-2021, on the basis of the autumn 2019 forecast of the EC

Chart 2: The GDP proportionate sovereign debt of the Visegrád Group of countries and the date of establishing the independent fiscal institutions

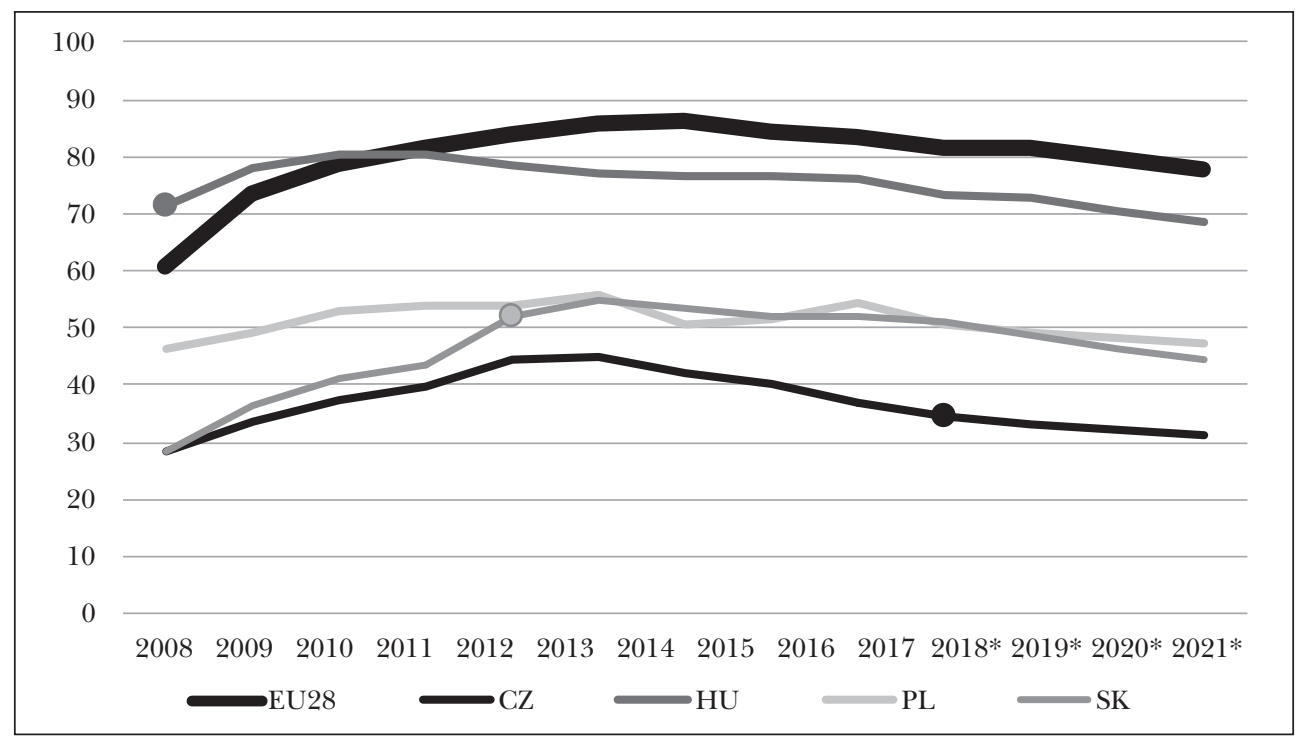

Source: Eurostat, 2019-2020, on the basis of the autumn 2019 forecast of the EC 
promoting the support of stability and growth conditions by fiscal means. Clearly we can reach the conclusion that the use of rule-based budgeting is favourably affecting problem solution, the promotion of strengthening financial management discipline and this favourable effect can be directly experienced mostly in the gradual easing of the burdens of indebtedness. We should note however, that the degree of the contribution of rule-based budgeting in the strengthening of financial stability to a large extent depends on the social-political will and, naturally, on the public authority respectively the strength of the said authorities of the institutions guarding over the compliance with this set of rules. ${ }^{13}$

\section{DOMESTIC FISCAL POLICY, INTRODUCTION OF RULE-BASED B U D GETING}

\section{Problems of managing public finances and the human factor}

Earlier we mentioned that specific national characteristic features and the lack of financial stability in the immediately preceding period are defining essentially the circumstances of the introduction. Having in mind this we cannot escape mentioning, why and how we have reached the conclusion in Hungary that in order to establish stability in the fiscal (budgetary) policy the introduction of rule-based budgetary frame is inevitable?

After the millennium Hungary was not the only country that had to face those increasingly hard to handle public finance, over expenditure and - as a consequence - ever deepening indebtedness issues that all led to the ambiguity of the financial stability of the country. However, the situation was somewhat different in case of our country because of the synergistic/antagonistic processes of the overlaps between the political and economic cycles that very likely have had a crucial role in over-expenditure - due to endeavours to maximise and/or get more votes - and thus in the growing indebtedness compared to other countries of similar fate ${ }^{14}$ (Karsai, 2006) .

As regards our fiscal policy it remained a fundamental feature that parallel with the amendment of our Constitution in 1989, then the signing in 1994 of the Contract of Association that was an opening step in the direction of the European Union and finally, in our determinations listed by the 2005 Accession Agreement to the EU that contained those requirements regarding the goals and the tools to be used in the course of the accession that expressed our connecting to a bigger group of those European countries that formed a social-economic-political community ${ }^{15}$ The association implied harmonisation obligations, incorporating the financial balance related requirements among joint European integration values and norms. ${ }^{16}$

In the context of our article it is obvious that reaching the desired goals depends not only on creating the appropriate regulations but also on the disciplined observance and enforcement of the said regulations. And in this the human factors, the ability of recognising social interest and the will to follow this road are getting an important role without the support of what the financial stability of a country can hardly be realised (Kovács, 2016). 
In Hungary, following the regime change, the fiscal policies of the subsequent governments were characterised by bargaining mechanisms, planning and financial management built on political promises and dogmas. This presented an obstacle for public finance stability as well as for sustainable development (Antal, 2004; Karsai, 2006; Lentner, 2008; Matolcsy, 2008; Muraközy, 2010).

From time to time public finance deficit was "skyrocketing" in Hungary (mostly in years around parliamentary elections). In 2002 and 2006 it reached close to the 10 percent of the GDP (Chart 3). ${ }^{17}$

Chart 3: Hungarian public finance deficit calculated by the EU methodology (ESA 2010)

from 1995 to 2010 (in the proportion of the GDP)

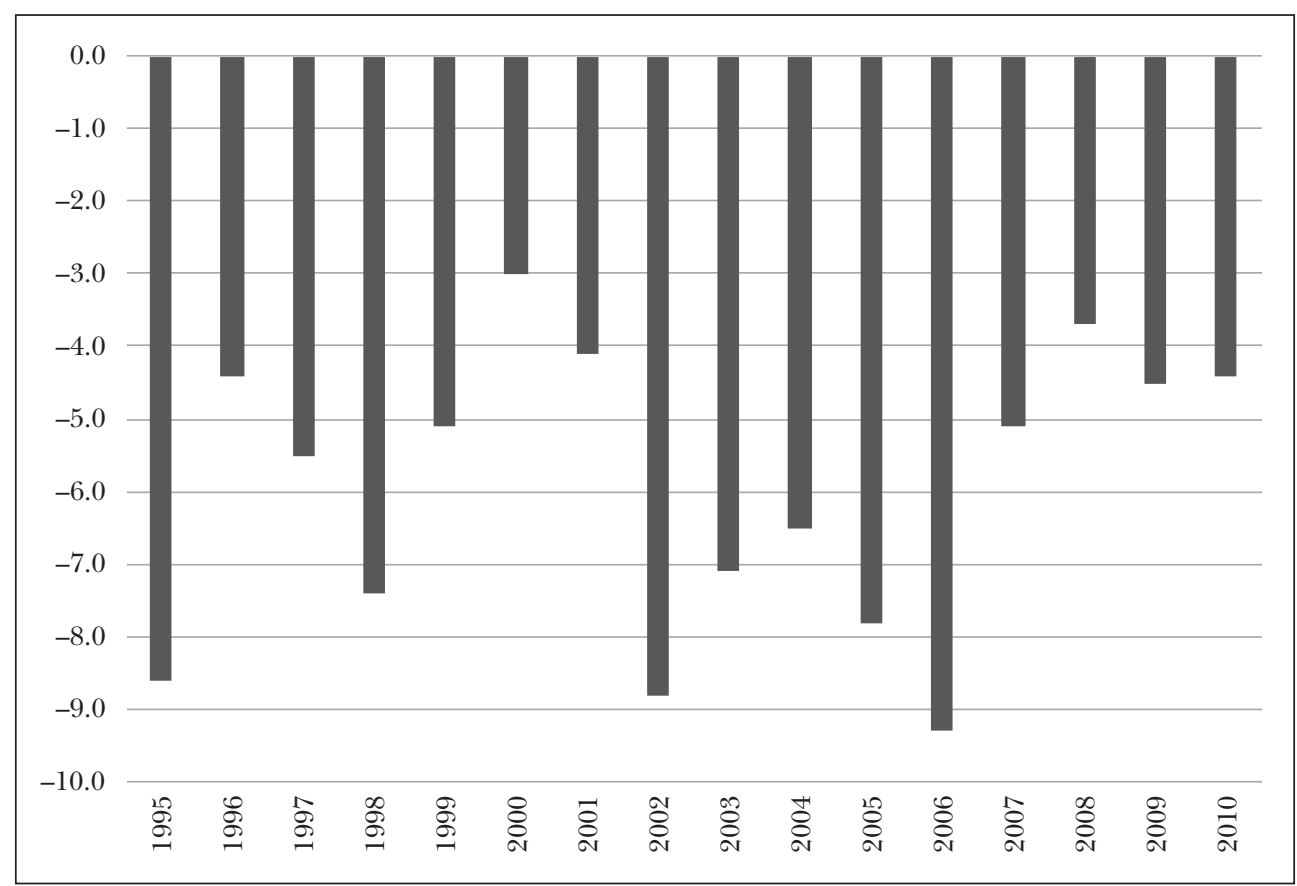

Source: Eurostat, FC Secretariat edition

It was the direct consequence of the high deficit that the degree of the GDP proportionate government debt (government debt rate) that beginning with 2000 years up to the introduction of the rule-based fiscal politics in 2010, the rate had increased continuously. Contrary to the ongoing emphasising of our European orientation and the country's commitment to follow the European examples, the promises made in the convergence programmes, the indicators regarding the balance of Hungarian public finance were getting farther and farther from those fiscal policy and technical balance regulations that the country had undertaken.

Not only the repayment of the government debt that skyrocketed in the first half of the $1990 \mathrm{~s}$ - to be followed by a temporary decline - and jumping up again in the 
years 2000, but also the very expensive financing of this debt (the debt service, i.e. the interest) meant/means an enormous burden for the country. "In the period of 1993-1999 the interest expenditures exceeded the amounts used for education, culture and health care" (György and Veress, 2016).

All we can add is that the debt service tied up the same proportion - 8-9 percent from the public finance expenditures allocated for healthcare and was hardly lagging behind the 10-11 percent allocated for the total of education expenditures for several years, even after 2010. (Today this burden represents 5 percent!)

Chart 4: GDP proportionate sovereign deficit, 1990-2010

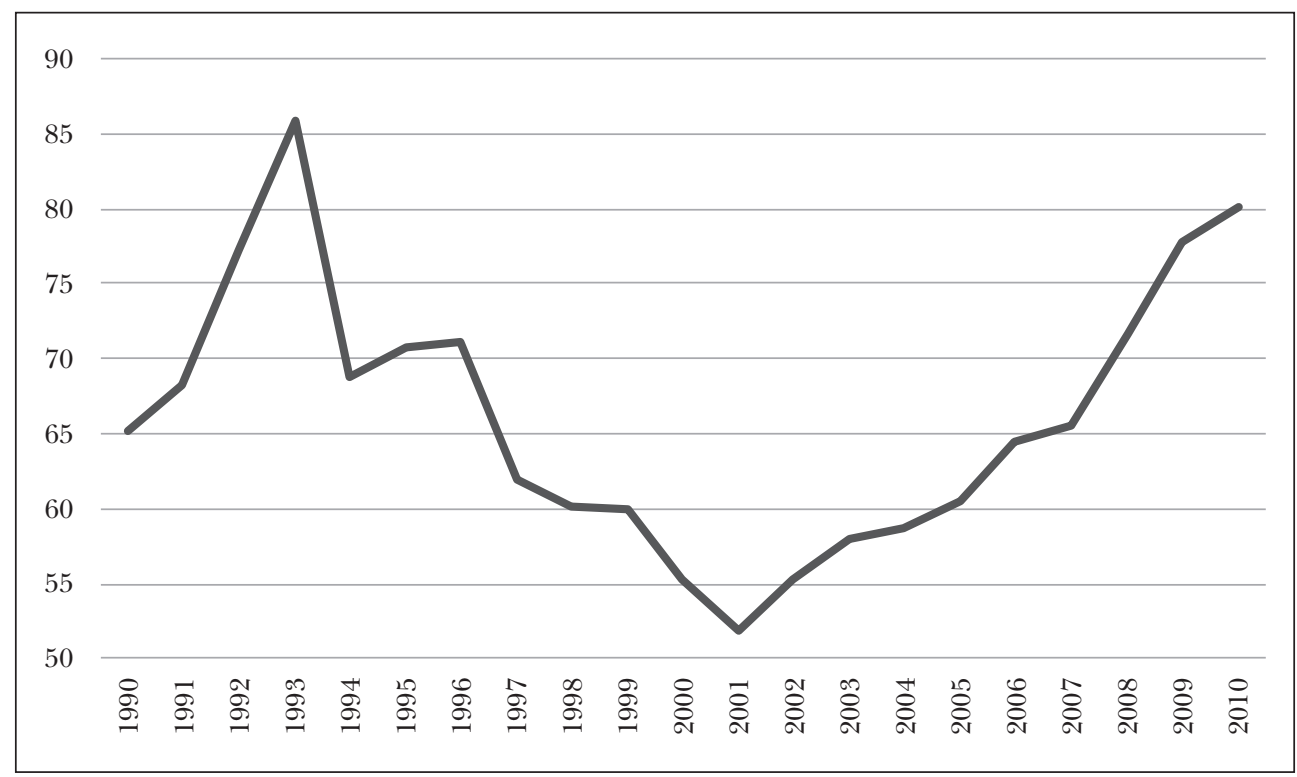

Source: Eurostat, FC Secretariat edition

The exceptionally high degree of Hungarian redistribution - around the outstanding 50 percent of the GDP - compared to the neighbouring countries but even to the average of the EU countries was the direct consequence of our fiscal policy.

It was inevitable that the significant income depletion (and within this the high tax centralisation) encouraged the amplification of black economy that led to the narrowing of the number of taxpayers, the erosion of tax bases and even higher tax rates. As a consequence, market sector investments decreased. The phasing out of companies from the credit markets was a factor in this.

Lack of social acceptance and support of the society were also playing a part in the fact that the public finance reforms and consolidation attempts announced by the succeeding governments following the change of regime proved to be unsuccessful or were merely partially successful during twenty years - with the exception of the 19962002 period that overreached governments. Another factor of this failure was that at 
that time there were no appropriate fiscal-political regulations, i.e. those checks that that could have adjusted the tasks undertaken by the state to the capabilities (taxation) of the country were missing and no requirements existed at the time that might have promoted the more efficient utilisation of public moneys and accountability.

The competitiveness of the country also worsened due to the (aforementioned) oversize public finances and its subsequent "greed", the non-efficient operation affected the national economy negatively. ${ }^{18}$

The above causes - together with a number of additional factors like, for example the lowering productivity - all present together in our county contributed to a more moderate growth rate and often, to the downturn of the growth rate respectively, maintaining the growth required ongoing mobilisation of external funds and indebtedness (see Chart 5).

Chart 5: Economic development of Hungary and the Visegrád Group countries from 1996 to 2010 (change of volume compared to the previous year, percent)

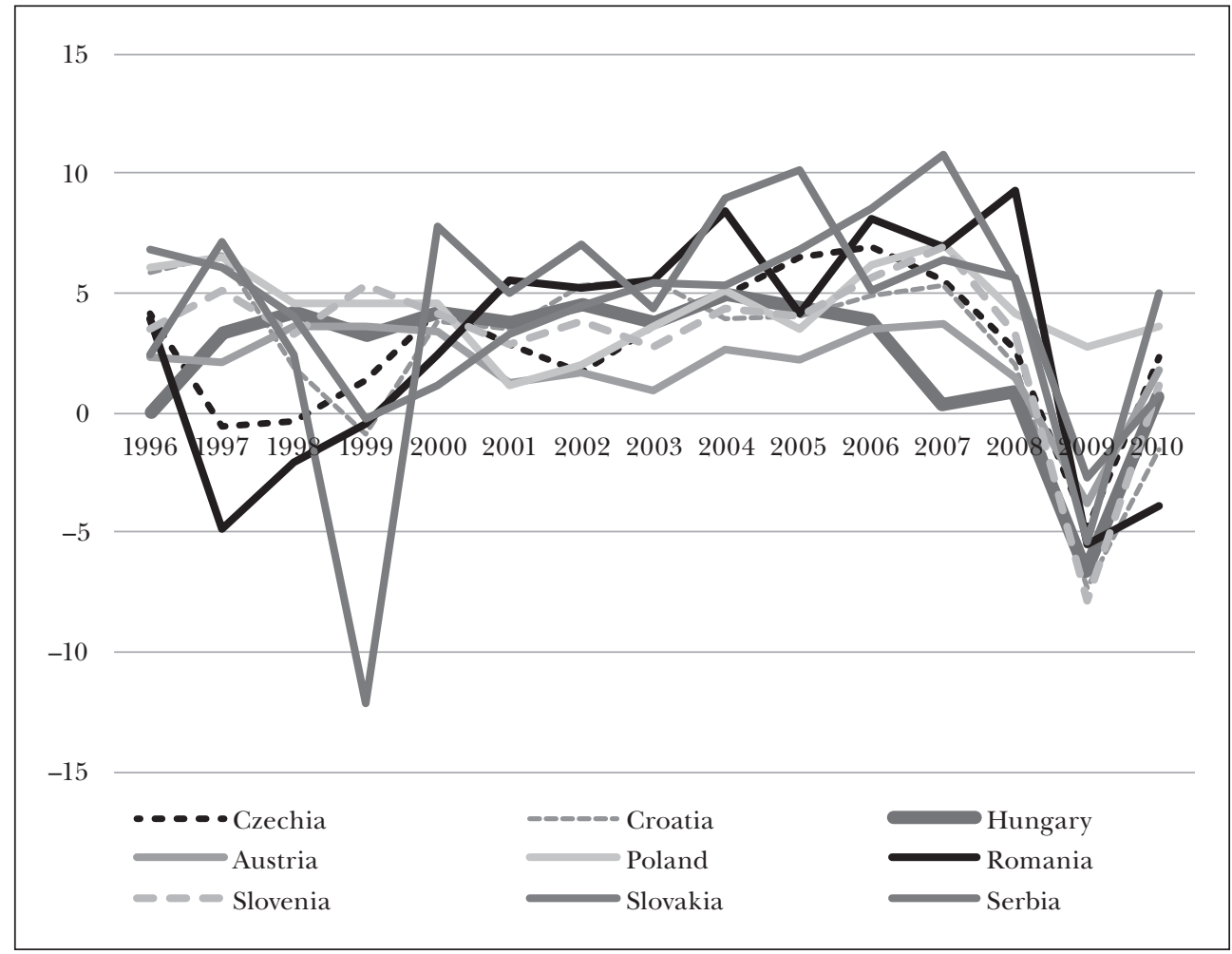

Source: Eurostat, European Commission, FC Secretariat Edition

Despite the predominance of public finances the population had the perception that the level of public services and thus their quality of life has been constantly worsening. In other words the perception was that their expectations were not met despite 
seeing/hearing them repeatedly in the election promises (Kovács, 2016). On top of this, the 2008 crisis that started from the money markets and became an ever more encompassing economic crisis found our country in this situation and thus contributed to further weakening our position.

\section{INTRODUCTION OF THE RULE-BASED BUDGETING IN HUNGARY - ANTEGEDENTS, INSTITUTIONAL SOLUTIONS}

As a result of the worsening problems of Hungarian public finances that had endangered the sustainable financing of the public finances and had a destructive effect on the competitiveness of the real economy, by 2006 it became clear that the budgeting practice being applied ever since the change of the regime excluded the chances of following the course of sustainable development. Change could not be postponed any longer and a substantial turnaround was necessary in fiscal policy; the question was what should be the content of this change.

Balancing on the brink of fiscal unsustainability led to the recognition that in order to maintain the financing public finances in a longer run government control shall have to ensure a regulation that was internally consistent and corresponding with the chosen scenario as well as a budget planning that was "thinking" about a longer period of time within the financial system of public finances, together with independent control guarding over the observance of the regulations.

\section{Double reflection period (2006-2007)}

As regards the character of the rules required for fiscal sustainability and the institutional guaranteed necessary for their observance experts were fundamentally thinking along two directions.

The Theses on the Regulation of Public Finances elaborated by the State Audit Office of Hungary assumed that in order to implement substantial changes, the whole of public finance management has to be regulated and made transparent and accountable. Namely, the experiences of this institution gained from its work proved that the weak effectiveness of the utilisation of public moneys due to the structure of public finances or the over expenditure guided by political purposes was impossible to correct subsequently and essentially by means of control. However, the understanding as regards the necessity and usefulness of comprehensive re-regulation proved to be insufficient for the realisation, due to the political division and under the conditions of a coalition government burdened by debates.

The other initiative that can be associated with the Central Bank of Hungary in its concept was focusing on the most important factor of fiscal tensions, i.e. the prevention of over-expenditure and considered the introduction the elements of rule-based budgeting - that proved to be successful in international practice - as a solution of the domestic problems. In 2007 and 2008 a lively professional debate evolved that was moving towards concrete solutions. 
The proposal combined by the Ministry of Finance, as an adaptation of the USA Congressional Budget Office, would have established the Budget Office of the National Assembly. Protracted consultations took place. According to the critics this concept could not find an adequate answer to the fundamental issue, how it would be possible to keep in harmony the undivided political decision-making authority and responsibility with professional control. According to other critics a decisive condition of observing the rules was missing, namely that they succeeded introducing reforms concerning the tax system and the great entitlement system in "critical mass". Apart from this they were of the opinion that from the aspect of implementation and efficiency this concept raised concerns.

After the proposal of the Ministry of Finance was taken off the agenda, the concept that aimed at the introduction of a regulatory framework targeting the mitigation of the deficit inclination and the prevention of over-expenditure became the sole concept on the table.

In the shadow of the threatening national insolvency and the pressure of the IMFEU borrowings, by the end of 2008 the act on cost-efficient state management was born that is often referred to as "ceiling act" due to its perception and intervention mechanisms (expenditure limits). Namely, by this act they were limiting the expenditure grand total of the budget for the next year (the amount planned for year 2009 had to be the same as the 2008 appropriation, while later the real value of the planned amount was allowed to grow by the half of the expected real growth of the GDP). Apart from this they created complicated rules for the envisaged balance of the budget just like for the envisaged degree of government debt. ${ }^{19}$

There were two different concepts as regards the Fiscal Council and its organisation. Although there was agreement that the chairman of the body should be an expert representing the head of the state however, as regards the members, there were different ideas. According to one concept the members should be the incumbent heads of two financial institutions, independent from the government, i.e. those of the SAO and the Central Bank of Hungary (MNB). In this concept the small secretariat basically should be focusing on summarising and planning tasks as the professional support of the Council's decision making work and would rely on the high level and significant macroeconomic analysing capacities of the SAO and MNB that otherwise have their respective, independent research and analysing staff and regularly analyse the soundness of budget planning. ${ }^{20}$

The other solution was essentially different from the above. In this case the expert representing the head of the state, heads of the SAO and MNB would make recommendations for the members of the FC. According to this concept the secretariat would be an apparatus with a significant staff funded by an independent budgetary source and had a distinct ability to do macroeconomic analyses.

Finally, in the "ceiling act" they opted for the latter version and that existed up to the end of 2010. From year 2011 they returned to the first concept and the conditions of the transitory period were regulated by the 2011 budget. ${ }^{21}$ The new Government established following the 2010 elections undertook the task of reviewing and setting 
in a new framework the whole of the legal system and within this of public finances, supported by a two-third majority in the parliament. This solution opened a new chapter in the regulation of the rule-based budgeting system that was in harmony with the importance of this issue.

The Fundamental Law of Hungary and the Act on the Economic Stability of Hungary about rule-based budgeting

The Fundamental Law of Hungary adopted on 18th of April 2011 dedicated a whole chapter to public finances. In this it stipulated the budgeting right of the National Assembly. Additionally it laid down that public finances should be managed in a transparent and in a verifiable manner, having in mind the requirements of legality, expediency and efficiency. At the same time it set up a barrier for indebtedness not only concerning the whole of public finance but within that for the local governments as well.

The Fundamental Law also defined the annually predictable measure of government debt when it created the government debt rule. According to this rule the National Assembly should not adopt such an act on the central budget as a result of what the government debt would exceed half of the GDP. As long as the degree of government debt exceeds this measure the National Assembly should adopt only such a central budget bill that contains the decreasing of the GDP proportionate government debt. ${ }^{22}$

The Stability Act concretely stipulates the government debt rule in a "debt formula" (see also the note no. 23). This rule formulated requirements not only regarding the planning and adoption of the budget but also regarding its execution. It determines that as long as the government debt is exceeding half of the GDP - with the exceptions laid down - no such loans shall be taken and no such obligations shall be undertaken as a consequence of what the proportion of the government debt to the total of the gross domestic product would increase the proportion of the previous year.

The Fiscal Council (or: Council, FC) guarding over the compliance with the rules of fiscal stability was elevated to the rank of the preconditions of constitutional operating by the Fundamental Law. The Council is a body that's task is supporting the legislative work of the National Assembly and carries out its work subject to the law. Among these tasks it is participating in the preparation of the central budget act and as an organisation supporting the legislative activities of the National Assembly it examines - formulates its opinion on - the soundness of the central budget on the one hand while, on the other hand it gives (or does not give) its preliminary consent for the adoption of the central budget act having in mind the compliance with the so-called government debt rule. In the process of creating the law by the latter task and mandate the Council, as an independent fiscal institution was endorsed by a public role, i.e. the so-called "right to veto" together with the responsibility that goes with it. The quotation mark is justified because the Council shall not annulate a decision, merely shall help it in the right direction.

This solution that implies a strong public mandate surpasses the practice existing in the majority of the EU countries where - as we could see in Tables 1 and 2 - the 
institution has a more of an awareness raising, advisory role that could be emphasised in a limited way by attaching them to a SAI or the parliament. The possibilities of direct intervention of the given institutions, bodies are modest most of the time. They can be characterised by an independent macro-analysing, forecasting (projection) work; the strength of the utilisation of their findings primarily are defined by the respect of the given institution, respectively the attention given to them by the actual government of the given country and/or parliament. Accordingly, the given fiscal institution characteristically puts the emphasis in its work on the preparation of multi-annual forecasts. Contrary to the Hungarian institution, where such longer term outlooks prepared by the experts assisting the work of the Council, are being used in the assessments of the body regarding the budget of the current year (Kovács, 2014; 2016).

As regards the tasks of the Council, the framework set by the Fundamental Law was detailed also by the Stability Act (see Chart 6).

Chart 6: Tasks of the Fiscal Council in the Stability Act

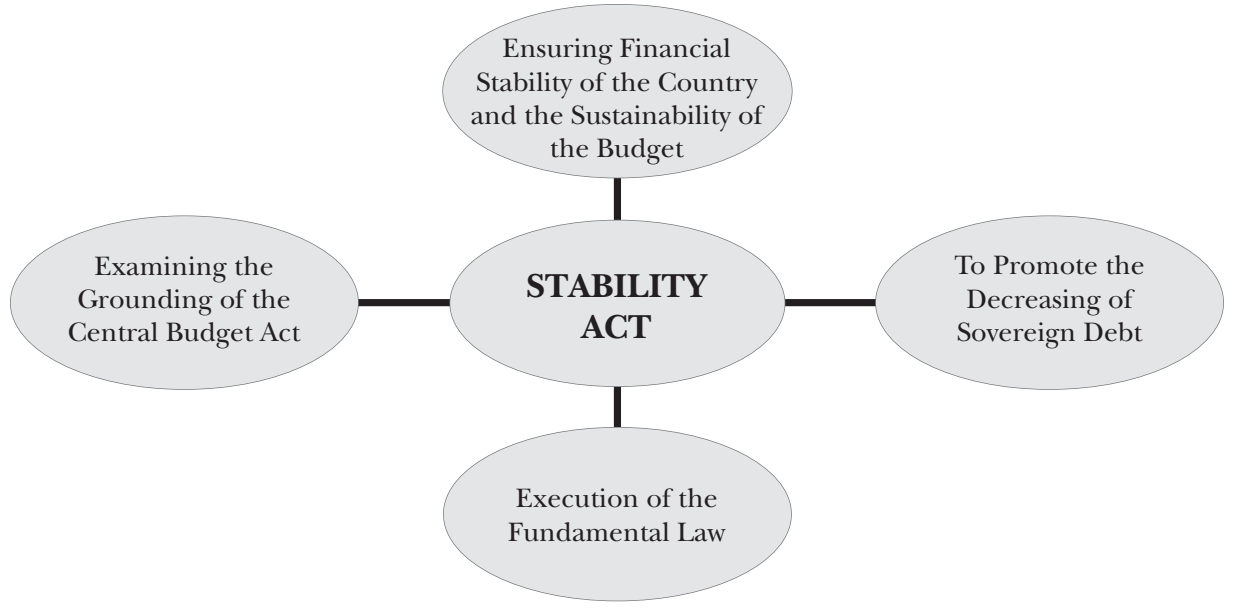

Source: www.kormanyhivatal.hu/download/3/de/20000/6\%20Stabilit\%C3\%A1si\%20t\%C3\%B6rv.pdf

It is the Stability Act that expounds in detail the procedural order to fulfilling the obligatory tasks of the Fiscal Council and the related tasks of the Government, focusing, first of all, on the adoption of the central budget bill (and its amendments). If, in case of formulating its opinion on the draft bill, the FC expresses its disagreement then the Government has to re-negotiate the bill and conciliate it with the Council. The procedural rule concerning the preliminary consent of the Council about the compliance of the draft budget with the government debt rule is even "tougher" if the FC - enforcing its veto right - refuses granting its preliminary consent the final voting has to be postponed and the procedure should be repeated until the Council gives its consent. 
Organically completing all the above, it is a priority task of the Council to formulate its opinion on the execution of the central budget act and the expected trend of sovereign debt every six months.

The FC is monitoring the planning and execution of the budget also in the context of the longer term macroeconomic processes. In this, beyond the analysing abilities of the $\mathrm{SAO}$ and MNB the Council is relying on the contributions of research institutions, external experts, professional fora and advisory bodies as well.

As regards the other, non-mandatory tasks of the Fiscal Council the Stability Act defines that it may express its opinion on the amendment of laws related to the budget act and any other issues that are related to the planning and execution of the budget, the use of public funds and the state of the public finances. In a wider context satisfying the interest of experts and the media, seeking the opinion of economists, fulfilling the demand for information by international organisations, cooperation with the independent fiscal institutions of other countries, promoting the public finance stability by means of publicity also belong among the duties of the Council (the resolutions, the annual action plan, other documents and used researches can be found on the Council's website)..$^{23}$

The activity of the Fiscal Council following the adoption of the Fundamental Law of Hungary and the Stability Act

By its tools, not least by its strong mandates that serve fiscal discipline, or we can say, by its guarantee-like presence, the activities of the FC have also contributed to the policy of fiscal balance as a significant consequence of what the proceeding of Excessive Deficit Procedure (EDP) against Hungary was terminated in 2013, respectively the parameters that allowed that the big international credit rating companies uniformly put Hungary in 2016 back to the category of recommended for investments were met. ${ }^{24}$

According to Point (3) Article 44 of the Fundamental Law the Fiscal Council's primary goal of operation can be summarised in ensuring the implementation of the rule about the decrease of sovereign debt. In its work the Fiscal Council has been consequent in focusing on this task. Accordingly, it was the annual analysis of the implementation of the compliance with the respective stipulations (expectations) of the Fundamental Law and the Stability Act promoting and maintaining public finance balance, the creating of budget laws and checking their execution that made up the focus of the Council's activities.

The annual and continuous GDP proportionate government debt is reflecting also the work of the Council (Chart 7).

The end of the year level of the GDP proportionate sovereign debt has been declining since 2011 and by 2019 it was below 67 percent (9 percent decrease). On the basis of the fiscal and macroeconomic processes the debt rate might fall below 60 percent by 2022, i.e. below the Maastrich criteria. It is now within reach that the euro area would be a result of many-facet (economic) political pondering and not merely the meeting of the accession's criteria. 
Chart 7: Trend of the GDP proportionate sovereign debt (percent) from 2008 to 2021

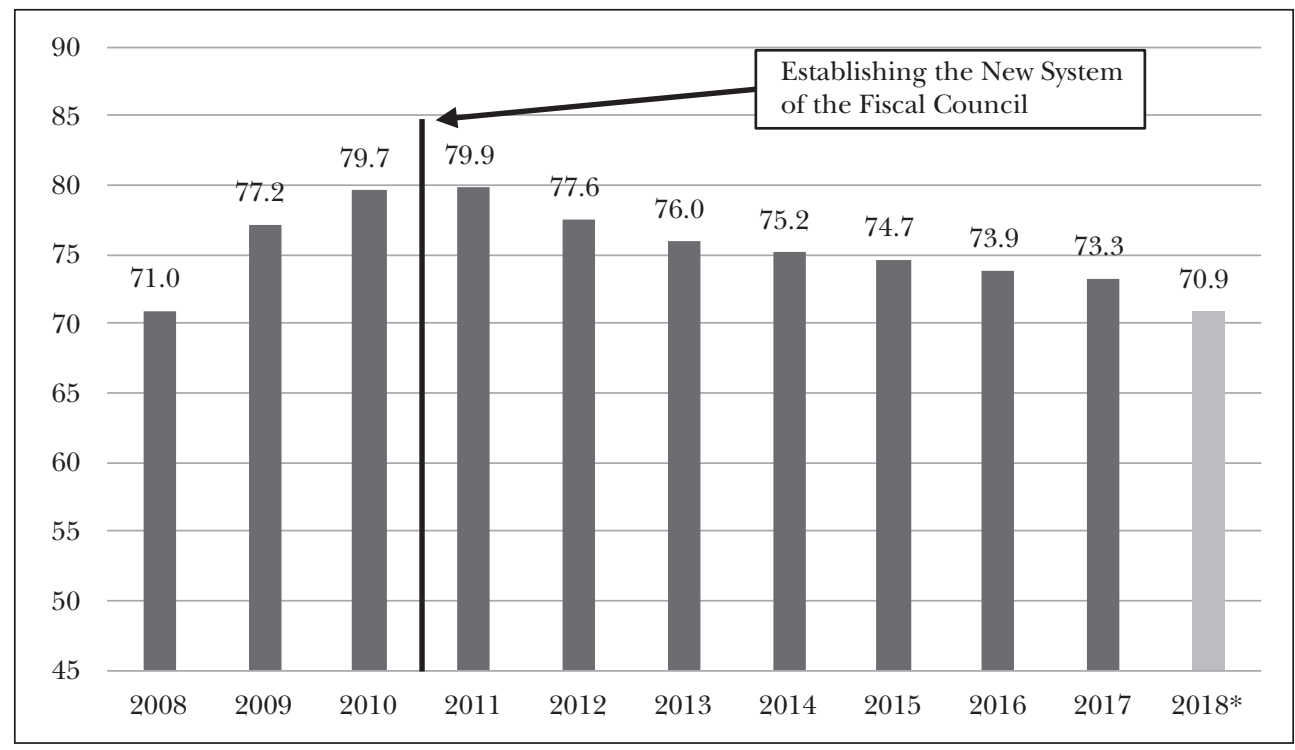

Source: Annual Discharges, MNB, FC Secretariat, 2019-2023 Preliminary Data

The effect of the FC's work was reflected also in the improving validity of the planning work of the government. Namely, in the second part of the reviewed period the need for amendments decreased and even then the reason was development and wages and salaries' oriented due to the improving revenue collection and the ensuing greater room to manoeuvre. Naturally, the strengthening of the stability of the budget and the fact that the macroeconomic growth was beginning to be sustainable, were important factors in this respect as well.

As regards the planning and execution of the budgeting process it was also favourable that contrary to the earlier legislative practice of doing it during the autumn and winter months, the adoption of the budget act was completed already in June-July. This has a positive impact not only on the public finance sector but also on the national economy in a wider sense as the business entities have a significantly longer period of time for the preparation of running the business in the next year.

Year after year the Council was paying attention not only to the exact planning of revenues, expenditures, deficit and sovereign debt but also made sure that aspects of efficiency were enforced on both the revenue and expenditure sides of public finance. The FC did this parallel with repeatedly emphasising that the competitiveness turn was unavoidable in the economy.

Additional technical and substantial characteristic features of the eight years' of functioning

In the period from 2012 to 2019 the Fiscal Council altogether made 71 resolutions (14 in 2012, 17 in 2014, 9 in 2015, 6 in 2016, 6 in 2017, 6 in 2018 and 6 in 2019) 


\section{Árpád Kovács: The Career of Rule Based Budgeting in Hungary}

when, in the course of performing its tasks was focusing on the balance, authenticity, reliability and the implementation of the government debt rule. From among these resolutions 61 were related to their opinion on the draft of the central budget bill (and the related amendments), the half-year evaluation of the implementation of the central budget act respectively, in connection with the final voting, granting the FC's preliminary consent; 10 resolutions were brought regarding the operation of the Council and the report on the body's activities in the previous year as well as the board resolution about the adoption of the FC Action Plan for the next year.

Taking a look at the decreasing number of resolutions and the contents of these documents the process of the stabilisation of Hungarian public finance can be traced. It shows that with the passing years there was less and less and finally no need at all for mid-year corrections or the amendment of the budget. The differences between the implementation data of the planned and realised budgets in 2016 and 2017 were the result of the changes in the EU financing cycles and not of internal, planning errors. ${ }^{25}$

On a basis of legal authorisation the SAO and MNB have continuously supported the Council in formulating its well-founded decisions by a number of studies, analyses (findings) prepared by the staff of these two institutions. Apart from these documents the 56 studies commissioned and utilised by FC from scientific, research institutes and market analysing companies dealing with a variety of issues were also playing an important part in these years.

In each year of the reviewed period, beyond enforcing the direct, governmental and parliamentary enforcement of FC's public law effect resolutions the Council was also affecting indirectly public finance and economy when the Chairman of FC, the staff of the Council and their representatives, as well as the heads and staff members of institutions that contributed to the work of the Council by researches, have held presentations that evoked great interest at conferences organised together with the Hungarian Economic Association. They regularly appeared in the media as well.

Following the emergence from the EDP procedure the Chairman of the Council initiated a line of consultations about the issues concerning the methodological rules of procedure and their topical changes with the President of the Hungarian Central Statistical Office and her experts. In these consultations they reviewed the types of national accounts, the respective issues of substance, the requirements of the EU Regulations 549/2013 issued by the European Parliament and the Commission (21st of May, 2013), and the effect of the topical Eurostat corrections on the GDP and GNI calculations. Members of the FC, respectively experts representing them were attended the consultations.

The Chairman of the FC ensured the opportunity for international financial organisations for meetings and exchange of opinions. Thus it informed the experts of IMF and OECD who regularly visit the country about the state of the central budget and issues of sustainability. Apart from this several time he received representatives of the EU Commission and the experts of international credit raging companies (Moody's, Fitch Rating, Japan Credit Rating Agency Ltd.) seeking information. Mem- 
bers of the FC and its experts were also attending these meetings or were informed about these events.

Apart from introducing the general characteristic features of the Council's work it is reasonable to include some concrete key decisions of the Fiscal Council too:

- In 2012 the FC asked for the elaboration of an alternative macroeconomic course and the significant increase of the so-called Country Protection Fund ${ }^{26}$ in connection with the year 2013 draft central budget bill as in the course of formulating the body's opinion they considered that the macro forecast used as a basis for the budget planning was not duly substantiated. As a consequence the Government prepared a new proposal with and amended macroeconomic background, targeted deficit and additional measures to improve the balance of revenues (tax system) and expenditures.

- In 2013 in the FC opinion on the draft of the 2014 central budget bill the body identified risks both on the revenue and expenditure sides. Thus they were on the opinion that strict and efficient financial management was necessary at all levels of public finance in order to comply with the implementation of the targeted balance. The FC also indicated that even if justified, the frequent amendments of laws resulted in decreasing accountability.

- In 2014 the Council called the attention to the necessity of more robust reserve maintenance as regards the 2015 budget bill to protect the macroeconomic course from external effects.

- As regards the aforementioned debt formula the FC wrote a letter to the Prime Minister in 2013 and initiated reviewing the formula as its methodology proved to be too strict and would have called for fiscal steps that might have endangered public finance balance and economic growth in 2016. In later years the FC repeated its recommendation several time. In 2015 it called the attention once again when analysing the 2016 draft of the central budget bill they were on the opinion that compliance with the debt formula was impossible to meet. Having in mind these antecedents finally the National Assembly adopted a new debt rule that was supporting growth.

- In 2016 in the debate of the draft of the 2017 central budget bill the Council welcomed this as a step taken towards a balanced budget (the separation of the operational and capital formation budget, recognising deficit only in case of the latter). This was the first time when the FC called the attention of the Government to the improper performance of the requirement concerning the so-called structural deficit. ${ }^{27}$

- When formulating an opinion in 2017 on the year 2018, and in 2018, on the year 2019 draft budget bill it was the issue of the examination of structural deficit that got in focus. The FC stated that it was exceeding the medium term targeted value. At the same time the body deemed it a positive sign that the difference has been decreasing every year.

- Furthermore, in connection with the draft budget bills of years 2018, 2019 and 2020 , it emphasised that the planned decrease of the GDP proportionate sovereign debt was meeting not only the domestic requirements but was also in harmony with the EU stipulations. ${ }^{28}$ 


\section{Árpád Kovács: The Career of Rule Based Budgeting in Hungary}

- In 2019 - according to the Council's emphatic opinion concerning the 2020 budget bill, the FC "deems it justified ... to take those measures that would ensure the improvement of productivity and efficiency as a result of what the growth rate exceeding the average of the European Union not only in 2020 but in the medium term as well".

- As a result of multiannual efforts it could be stated that in the course of the past years the share of foreign currency denominated debt within government debt exceeding 50 percent in the years of 2010 has decreased by the end of 2019 to approximately 10 percent and has significantly contributed to the mitigation of the external vulnerability of the county.

Stability of Hungarian finances as the basis of the ability to grow and of efficient functioning

The improvement of public finance balance is acting as a stimulus as regards growth both in our country and our neighbours. The success of our rule-based budgeting policy is reflected not only in the decreasing public finance debt but also in the fact that ever since 2012 our primary balance has been continuously positive in contrast to the previous years when we succeeded reaching such a favourable result only in certain years (Chart 8).

The improvement of public finance balance is acting as a stimulus as regards growth both in our country and our neighbours. The success of our rule-based budgeting policy is reflected not only in the decreasing public finance debt but also in the fact that ever since 2012 our primary balance has been continuously positive in contrast to the previous years when we succeeded reaching such a favourable result only in certain years (Chart 9).

As a result of the significant improvement of the work targeting the effectiveness of revenue collecting and keeping expenditures under control contributed to the improvement of deficit indicators and following 2010 the government debt rate has been decreasing each year (as we saw on Chart 7). By the improving balance the budget can be financed by smaller costs. And cheaper financing exempts resources primarily for economic development and thus is a growth factor. This is setting the foundations for the increasing of resources for social and welfare (healthcare, education, social matters) expenditures. From the aspect of the vulnerability of the national economy and judging the public finance the dramatic fall of the foreign currency denominated share of sovereign debt (see Chart 9 ) is especially advantageous. In this respect it is just as important if not more important that by the end of year 2018 - following a similar path - the share of debt owned by domestic hands has grown to the detriment of external grantors.

The economic growth determining public finance stability has been present ever since 2013. We should emphasise that years 2014 and 2015 were the first two years ever since the early 90s when Hungarian economy was able to grow in such way that the growth was not followed either by the growth of sovereign debt or that of the external indebtedness of the economy. It is favourable that economic recovery is gaining 
Chart 8: Deficit of the Hungarian Public finance, its net interest expenditures, primary balance in the proportion of the GDP, 2008-2018

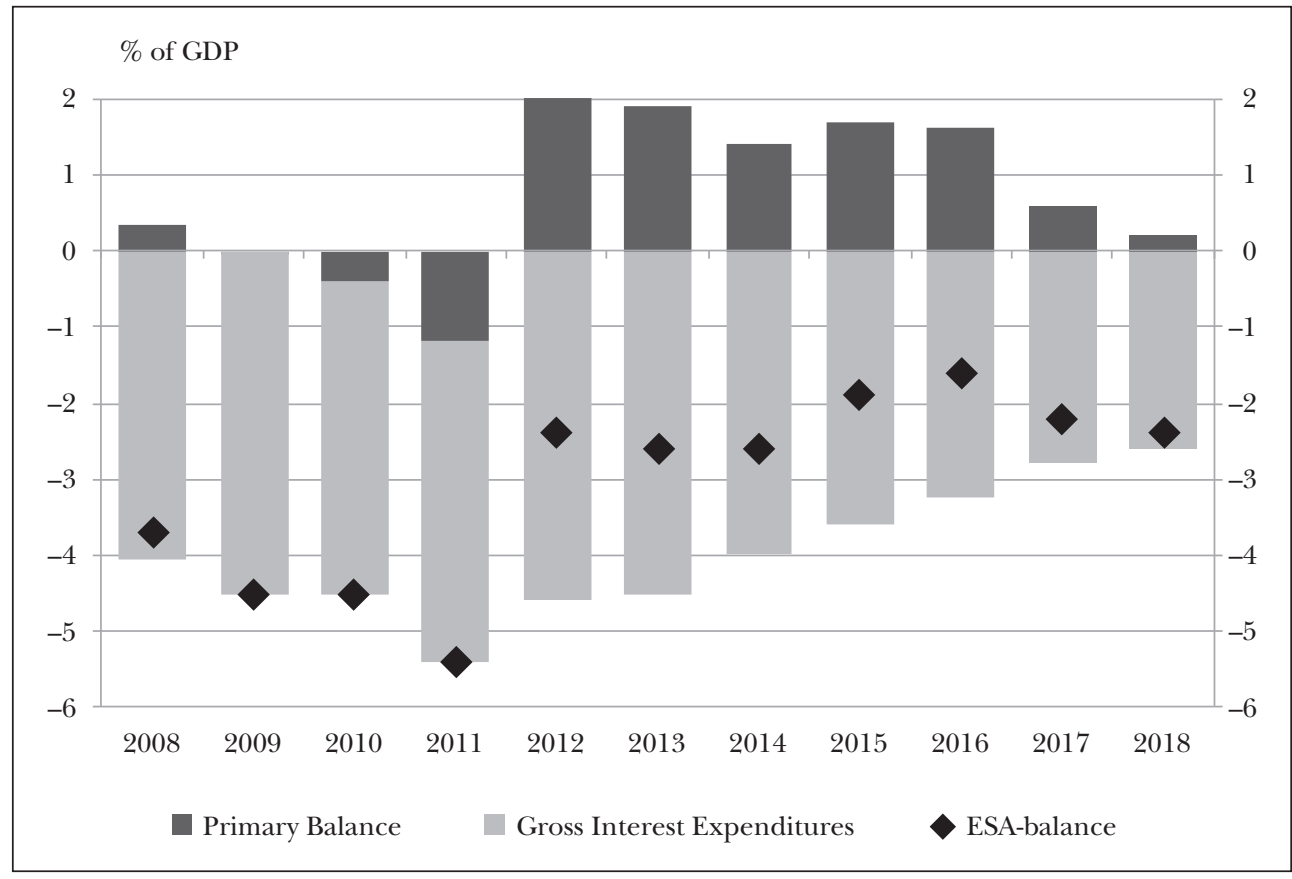

Note: At the time of closing the manuscript the 2019 data is not known yet.

Source: $M N B$

Chart 9: GDP proportionate sovereign debt of Hungary denominated in foreign currency

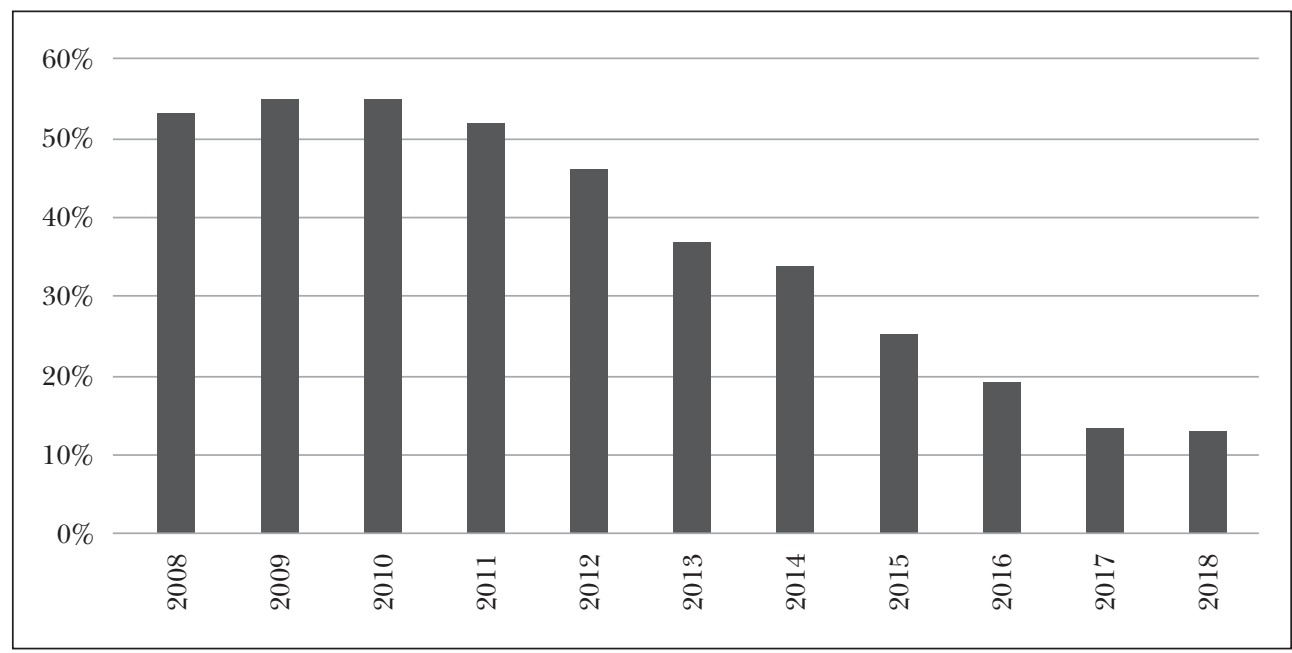

Note: By 2019 it decreased further (no concrete data was available yet at the time of finishing the manuscript). Source: ÁKK, FC Secretariat Edition 
strength and the economic growth of the region is exceeding the average of the euro area (see Chart 10). As regards the chart, we should note that the expansion of the Hungarian economy in 2018 reached 4,9-5 percent that exceeded by far the last forecast of the European Commission (2018) and the data from 2019 is similar to this. As regards the following years it is likely that the Hungarian economy will perform above the average of the $\mathrm{EU}$, in the area of 3-4 percent.

Chart 10: Economic growth of the Central-Eastern European regions and the euro area in the period of 2008-2021

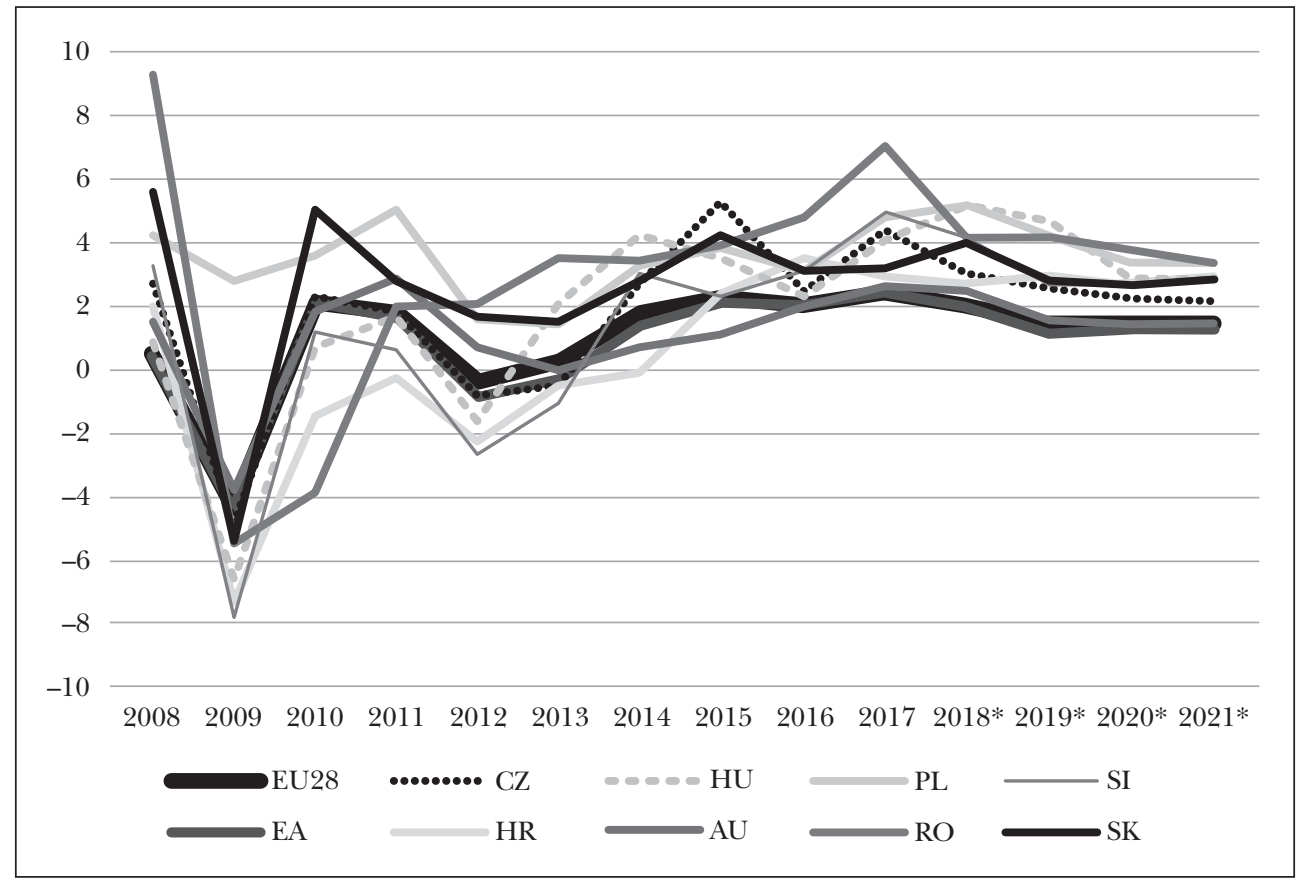

Source: Eurostat, European Commission, 2018

\section{SOME FINAL THOUGHTS}

The specific characteristic of the "Hungarian model" that was renewed in 2011 is that to prevent the earlier fiscal indiscipline the FC was granted public law authorisation (the right to veto) concerning the adoption of the budgets (and their respective amendments). As a consequence, the body is primarily focusing on the risks threatening the stability of the given year and the year beyond. It utilises the medium term outlooks, forecasts subordinated to this philosophy. Although the Council does not elevate such documents to the rank of board decisions, in its work the ideas concerning the sustainability on medium and longer terms are getting more and more in focus concerning the harmonious sustainability rather, increase of the economic, environmental, competitiveness and social welfare. 
It can be said that it is not solely because of the strong authorisations of the strict stipulations, the simple and transparent principles of the Hungarian system, the principles that are focusing on fighting government debt and the stipulations guarding the observance of the rules that make its successful operation possible but also the solutions of the Hungarian regulation that is adjusting to the European practice in a specific context, its effect of moderating over-expenditure, its awareness raising and confidence creating power as well as its timeliness have all contributed to its success. This is how it can contribute to the stability of the country, sustainable development, the improvement of the country's competitiveness, to the efficiency operation of the public finances sector and finally, the rising of the nation, the citizens of the country and material well-being.

Thanks to employing the elements of rule-based budgeting and the activities of the Fiscal Council - strengthening the requirements applicable for them both in the Fundamental Law and the Stability Act - in the years following 2011 the public finance balance clearly started to improve concerning the indicators of deficit and indebtedness. The stability of the central budget makes it possible that public finance assisted the development of the economy to an ever growing degree (today it represents the double of the data of the 2010 years). The competitiveness indicators ${ }^{29}$ however are lagging behind the indicators of the Visegrád group of countries even today, despite their having shared a similar fate to us. At the same time, from among the line of our weaknesses those factors that were related to the poor efficiency of the functioning of the Hungarian public finances and that - by withdrawing resources from the economy - were the reason why competitiveness of the Hungarian economy eroded in the period 2004-2010 and embody the causes that are difficult to outgrow.

Our balance situation if exerting a positive effect on our national competitiveness. ${ }^{30}$ The development of efficiency enhancing and innovation factor that are able to lay solid foundations for competitiveness and economic growth, like vocational and adult education, higher education, innovation system, optimising the coordinating mechanisms of the economy and cutting back the bureaucratic and administrative burdens of the market actors, can take place if we maintain the balance of stability and growth (György and Veress, 2016).

We can say that thanks to the economic performance of the country and the disciplined, committed to the principles and implementing the practice of rule based public finance management, the observance of the system of financial norms of the EU stipulated by public, normative regulations - at least its regulations related to financial stability and sustainability - Hungarian fiscal economy came close to the European standards in a period when a government professing itself to be committed to "national" causes was leading the country.

\section{Notes}

1 The author wants to thank Tünde Gregich and Dániel Csomós, staff members of the Fiscal Council Secretariat, to Messrs. László Kékesi and Sándor Varga, advisers to the Chairman, who assisted him in writing this article. The article is a revised and amended with new experiences version of the paper pub- 


\section{Árpád Kovács: The Career of Rule Based Budgeting in Hungary}

lished in Polgári Szemle, issue 13 in 2017 in Hungarian and English languages titled Rule-Based Budgeting: The Road to Budget Stability that was followed by a Chinese language edition of Polgári Szemle in 2019.

2 10th OECD Network of Parliamentary Budget Officials and Independent Fiscal Institutions (PBO) Seoul, 3-4 July 2018

3 The introduction and application of the rule-based budgeting has a very extensive theoretical literature and the EU Commission - moreover and lately the cooperation forum of the independent fiscal institutions of the EU member-states started to publish documents. This chapter was prepared by using these referred documents.

4 Indent (1) Article N of the Basic Line of our Fundamental Law („Hungary shall observe the principle of balanced, transparent and sustainable budget management.”) and Articles 36, 37 and 44 of the chapter The State on public money.

5 Act CXCIV of 2011 on the Economic Stability of Hungary.

${ }_{6}$ In October 2015 the European Commission established the independent fiscal institution of the European Union, the European Fiscal Board as an opinion giving, advisory body the activities and mandate of what were limited to the countries of the euro area. According to the resolution this new body functions independent from the national and European institutions but in cooperation with them. Members of the board were appointed a year later, in October 2016 by the European Commission and started its activities following this.

7 Although in Poland constitutional regulation provided the framework for the rule-based budgeting, it is the government, as an integral part of the executive power responsible for the execution of the budget, is overseeing its observance.

8 It was after 2008 when they started to use stricter fiscal regulations and established institutions to protect and „oversee” them in Germany, Ireland, Portugal, Finland, Austria and Italy. The countries that have already had such institutions (Sweden in 2007, Denmark and the United Kingdom in 2010) they further developed the system.

9 Up to 2017 none of the rule based fiscal framework elements have been used and the fact that the former Czechoslovakia could not get external resources due to political reasons was playing a significant part in this. The change of the regime here took place in a country where the economy was relatively developed, the standard of living was low however, the level of indebtedness was minimal.

10 The cooperation forum of the IFIs offers an organisational framework for this, and works with the ECFIN in the background. From 2015 the professional and consultation forum established as a self-assembly initiated mutual exchange of experiences with the European Fiscal Board to share best practices.

11 There are no international (European) best practices regarding the concepts of professional background or public law status of independent fiscal institutions. The important thing is the ability of institutionalised preservation of rules that varies from country to country as regards the strength of the employed public law tools, the degree of relying on different confidentiality and authenticity (respect) values and traditions, differently organised professional support, using different public law or institutional tools. One difference however is especially obvious that concerns the strong public law authorisations and the right to veto as regards the adoption of the budget when it comes to the Hungarian Fiscal Council. (We are going to deal with this later.) The guaranteed to keep budget deficit under control, to prevent over-expenditure or the regulations intended to limit the investment expenditure (Benczes and Váradi, 2011) can be interpreted together with the structure of the state organisation and its fiscal system (Török, 2011). There are a number of experiences in international practice where the basic analyses serving the validation of the body's decisions are acquired from the business sector or other, independent institutions - SAI, national bank, professional task force. From the countries of the European Union France, Finland, Lithuania, Latvia and Italy are building on their respective SAIs, while Slovakia and Austria opted for their national banks as professional background. In case of the latter solution we also have to note that in these countries an institution with parliamentary powers is also guarding the rule-based budgeting.

12 The cooperation of the Czech Republic, Poland, Hungary and Slovakia are behind the name "Visegrád" group of countries. In 2017 this group gave 5.6 percent of the GDP of the European Union and the name refers to the cooperation agreement of these countries signed in Hungary, at Visegrád in 1335. 


\section{Civic Review · Vol. 15, Special Issue, 2019}

13 Such could be for example when the IFI prepares the macroeconomic forecast that serves as the basis of the budget plan, gives its opinion on the draft budget bills, the defined budget parameters (proportion of the sovereign debt compared to the GDP, deficit ceiling, etc

14 Gábor Karsai wrote in 2005: „In Hungary the amplitude of the cycles of domestic politics appears more powerful than it is common in the old EU member states. Very likely this is partly the consequence of the greater tensions brought along by the transformation and partly of the more modest democratic traditions. ... The declared principles and practice the programmes announced in the election campaigns and those declared in the government programmes and laws should be clearly differentiated in the Hungarian economic and privatisation policy. This has two important elements. On the one hand these processes took place without parliamentary regulation" (Karsai, 2005, p. 510).

15 See Act XXXI of 1989, Association Agreement, Act I of 1994 EU Accession Treaty, Act XXX of 2004.

16 Acquis Communautaire, the basic principle of the community law. Literally it stands of ,jointly achieved" things and according to the Hungarian translation means "community achievements”. Instead of the expression 'acquis communautaire' lately they are often referring to it as 'acuis de l'Union' that is encompassing the „achievements” born in the second and third pillars of the European Union

17 Chart 3 shows the evolution of the accrual-based deficit (according to ESA 2010). We are aware that the public debt ratio is not directly affected by this, but by the cash flow deficit. The bottom line is that the effect is evened out over a longer period.

18 Naturally, this problem is present in a far wider context than this however, discussing it - amount them especially the impact assessment of productivity efficiency - far exceeds the frames of this article.

19 Act LXXV of 2008 on the Cost-efficient State Management and Fiscal Responsibility.

20 The small secretariat can be linked either to the SAO or MNB to thus ensure the technical conditions of the FC operation but it could also be expedient if the office of the National Assembly ensures the technical background for the operation. There are examples for all the above in international practice.

21 The changing ideas of establishing an institution or the concept of formulating its mission exceed the frames of this article. The Fiscal Council can be found in the Kovács, 2016.

22 According to Article 36 of the Fundamental Law as long as the government debt is exceeding half of the total gross domestic product the National Assembly shall adopt only such a budget act that contains the decrease of the proportion of government debt to the total gross domestic product. According to $\S 4$ of the Stability Act the amount of the government debt planned for the last day of the budget year. According to the valid regulation in 2019 if the rate of inflation forecasted for the budget year and the real growth rate of the gross national product (GDP) equally are exceeding 3 percent, the growth rate of government debt compared to the previous year shall not exceed the difference of the expected inflation of the budget year stipulated by the budget act and the half of the real GDP growth. In case from among the inflation rate forecasted for the budget year and the real GDP growth rate at least one does not exceed 3 percent the government debt decrease shall have to be at least 0.1 percent. According to the amendment of the Stability Act valid from January 1, 2020 and to be considered when preparing and adopting the year 2021 central budget of Hungary the degree of government debt shall have to be defined so that the decrease of the value of the government debt indicator compared to the reference year should reach minimum 0.1 percent apart from the observance of the EU regulations concerning the decreasing of government debt.

${ }^{23}$ www.parlament.hu/web/koltsegvetesi-tanacs.

24 Most recently (15th of February, 2019) Standard \& Poor's upgraded Hungary from BBB/A-3 to BBB/A-2 while Fitch Ratings upgraded the country from BBB minus to BBB (22nd of February 2019).

25 In 2016 the growth rate that determined the micro course of the national economy was $2.3 \%$ and was realized on the level of potential emission. And in 2017 the cash flow deficit was significantly better than the planned degree.

26 Apart from the nominated, reserves to be constituted compulsively the central budget bill may provide regulations for the establishment of other reserves. Such is the Country Protection Fund that ensures the maintaining of fiscal balance. 


\section{Árpád Kovács: The Career of Rule Based Budgeting in Hungary}

27 Structural deficit: the balance of the governmental sector cleaned of the effects of the economic cycles and individual items (Áht. Point y) Indent (1) § 2). Its extent shall not be higher than the 1.5 percent stipulated as a medium term fiscal goal by Point a) Indent (2) § 3/A of the Stability Act.

28 According to the so-called one-twentieth rule of the EU the GDP proportionate government debt shall not exceed 60 percent. In case it is higher than this limit then the difference shall have to be decrease annually by one twentieth part of the reference framework of the previous three years.

29 Attila Chikán wrote: ,a fairly strong correlation exists between labour productivity and competitiveness. We are hardly making a mistake when we say that one of the important factors of our country's significant lagging behind is that in the rank of the 33 OECD countries only five countries are behind us and Hungary's indicator is not reaching half of the USA data and represents exactly 60 percent of the OECD average. Having such results it is inevitable to detect overall backlog and it is an especially regretful fact that the growth rate of productivity is also showing a downward trend" (Chikán, 2014).

30 Continuing the thought of linking competitiveness and the rising of the material and spiritual wellbeing of the citizens we have to agree with the definition of Prof Dr Magdolna Csath according to what: „economy is competitive if the abilities of the nation are used well and keep gaining strength in a longer run, the firms are producing big additional value and as a consequence of these factors the standard of living and the quality of lives of the people is constantly improving" (Csath, 2016, pp. 5-6).

\section{REFERENGES}

Adema, M. (2008): Budgeting under expenditure rules in the Netherlands. www.rgs.mef.gov.it/_Documenti/ VERSIONE-I/Comunicazione/Eventi/WORKSHOP-2/ADEMAA-Fiscal-discipline-and-public-sectorefficiency.pdf.

Antal, L. (2004): Fenntartható-e a fenntartható növekedés? Az átmeneti gazdaságok tapasztalatai [Is sustainable growth sustainable? Experiences of transitional economies]. Közgazdasági Szemle Alapítvány, Budapest.

Báger, G. (2006): Program Budgeting-characteristic Features and Practical Experience. Public Finance Quarterly, Vol. 51, No. 3, pp. 284-305.

Balatoni, A. and Tóth, G. Cs. (2012): Az új magyar adósságszabály értékelése [Evaluation of the new Hungarian debt rule]. Közgazdasági Szemle, Vol. 59, No. 10, pp. 1107-1137.

Bod, P. Á. (2013): Crisis After Crisis - Any Lessons Learnt? Hungarian Review, Vol. 4, No. 2, pp. 18-28.

Benczes, I. and Váradi, Sz. (2011): Aranyszabály helyett adósságfék - a német példa [Debt brake instead of a golden rule - the German example]. Köz-Gazdaság, Vol. 6, No. 2, pp. 91-103.

Besley, T. and Scott, A. (2010): A New Watchdog Would Guard Us From Debt. Vox, www.voxeu.org/index. php?q=node $/ 4680$.

Chikán, A. (2014): A magyar társadalom fejlôdési esélyei a gazdasági versenyképesség tükrében [The Hungarian society's prospects for development in light of economic competitiveness]. In: Kolosi, T. and Tóth, I. Gy. (eds.): Társadalmi riport 2014 [Social report 2014]. TÁRKI, Budapest, pp. 589-602.

Csaba, L. (2007): Átmenet vagy spontán rendetlenség? [Transition or spontaneous disorder?] Közgazdasági Szemle, Vol. 54, No. 9, pp. 756-773.

Csath, M. (2016): Versenyképesség és egészségügy [Competitiveness and healthcare]. Interdiszciplináris Magyar Egészségügy, Vol. 15, No. 8, pp. 5-6.

Domokos, L. (2015): A Költséguetési Tanács és az Állami Számvevốszék tevékenysége közötti szinergiák [Synergies between the activities of the Fiscal Council and of the State Audit Office]. State Audit Office of Hungary, www.asz.hu/storage/files/files/Publikaciok/Domokos_Laszlo/a_kt_es_az_asz_tevekenysege_kozotti_szinergiak.pdf?download=true.

Franco, D. (2011): Comments on "The Role of Fiscal Policy Councils in Theory". Conference on "Fiscal Policy Councils: Why do we need them and what makes them effective?" Vienna, 31 January.

György, L. and Veress, J. (2016): The Hungarian Economic Policy Model After 2010. Public Finance Quarterly, Vol. 61, No. 3, pp. 360-381.

Hamilton, H. W. (1919): The Institutional Approach to Economic Theory. The American Economic Review, Vol. 9, No. 1, pp. 309-318. 


\section{Civic Review · Vol. 15, Special Issue, 2019}

Karsai, G. (2006): Ciklus és trend a magyar gazdaságban 1990-2005 között [Cycles and trends in the Hungarian economy]. Közgazdasági Szemle, Vol. 53, No. 6, pp. 509-525.

Kopits, Gy. (2013): Restoring Public Debt Sustainability. The Role of Independent Fiscal Institution. Oxford University Press, Oxford.

Kovács, Á. (2013): Crisis Management Similarities and Differences in the Newly Accessed Central and Eastern Europien Countries. In: Farkas, B. (ed.): The Aftermath of the Global Crisis in the European Union. Cambridge Scholars Publishing, Newcastle upon Tyne, pp. 152-177.

Kovács, Á. (2014): Fiscal Councils in the Countries of Eastern-Central Europe. Public Finance Quarterly, Vol. 59, No. 3, pp. 326-345.

Kovács, Á. (2016): The Fiscal Council in the Hungarian Fundamental Law. Sketch on the Development of the Institution and the European Union Practice. Public Finance Quarterly, Vol. 61, No. 3, pp. 312-330.

Kovács, Á. (2019): A magyar költségvetés „európai” szemmel - diagnózis és anamnézis [The Hungarian budget from a European perspective - A diagnosis and an anamnesis]. In. Kovács, L. P. (ed.): Közel Európa távol [Nearby Europe far away]. Éghajlat Kiadó, Budapest, pp. 287-321.

Kovács, O. (2013): A transzformatív erejû fiskális konszolidáció közgazdaságtana. Elmozdulás az innovatív fiskális politika koncepciója felé [The economics of transformational fiscal consolidation. A move towards the concept of innovative fiscal policy]. PhD dissertation, University of Debrecen, Debrecen.

Kutasi, G. (2012): Fiskális szabályok és intézmények az EU-ban [Fiscal rules and institutions in the EU]. International Relations Quarterly, Vol. 3, No. 1, pp. 1-11.

Lentner, Cs. (2008) A pénzügypolitikai stratégiaváltás kényszere [The compulsion to change the financial policy strategy]. In: Pulay, Gy. (ed.): Globális lendkerekek. Gazdasági-pénzügyi tanulmányok Báger Gusztáv 70. születésnapjára [Global flywheels. Studies in economics and finances. For the 70th birthday of Gusztáv Báger]. State Audit Office of Hungary, Tiszatáj Alapítvány, Budapest, Szombathely, pp. 191-201.

Matolcsy, Gy. (2008): Éllovasból sereghajtó. Elveszett évek krónikája [From the vanguard to bringing up the rear: a chronicle of lost years]. Éghajlat Könyvkiadó, Budapest.

Muraközy, L. (2010): Fenntartható-e a fenntarthatatlan „fejlôdés”? [Is the unsustainable growth sustainable?] In: Muraközy, L. (ed.): Válságban és válság nélkül. A gazdaságpolitika rétegei [In crisis and without crisis. Layers in economic policy]. Akadémiai Kiadó, Budapest, pp. 9-40.

Muraközy, L. (2011): Összefonódó költségvetési kihívások a 21. század Európájában [Intertwining challenges to the budget in the 21st-century Europe]. Közgazdasági Szemle, Vol. 58, No. 7-8, pp. 592-618.

Ódor, L. (2014): The Good, the Bad and the Ugly. CBR Discussion Paper, No. 3/2014, www.rozpoctovarada. sk/download2/gbu_final.pdf.

Orbán, G. and Szapáry, Gy. (2006): Magyar fiskális politika: quo vadis? [Quo vadis: Hungary's fiscal policy] Közgazdasági Szemle, Vol. 53, No. 4, pp. 293-309.

Reinhart, C. M. and Rogoff, K. S. (2010): From Financial Crash to Debt Crisis. NBER Working Paper, No. 15795, www.nber.org/papers/w15795.

SAO (2007): Theses on the Regulation of Public Finances. State Audit Office of Hungary, April 2007, https:// asz.hu/storage/files/files/Angol_portal/Other_publications/t173.pdf?download=true.

Sombart, W. (1929): Economic Theory and Economic History. The Economic History Review, Vol. 2, No. 1, https://doi.org/10.1111/j.1468-0289.1929.tb00774.x.

Török, Á. (2011): Intézményépítés a túlzott államadósság elleni védekezés érdekében [Institution-building in the interest of protection against excessive public debt]. Közgazdasági Szemle, Vol. 58, No. 7-8, pp. $577-591$.

\section{WEBSITES, DOGUMENTS}

Austria: www.parlament.gv.at/WWER/PDION/L/L3/L3_3.shtml.

Belgium: http://docufin.fgov.be/intersalgen/hrfcsf/onzedienst/Onzedienst.htm.

Croatia: www.mfin.hr/hr/odbor-za-fiskalnu-politiku.

Denmark: www.dors.dk. 


\section{Árpád Kovács: The Career of Rule Based Budgeting in Hungary}

Draft Principles for Independent Fiscal Institutions, background document $\mathrm{N}^{\circ} 1$ for Session on draft principles for independent fiscal institutions 33rd OECD Senior Budget Officials Meeting, Reykjavik, Iceland, 7-8 June 2012.

European Commission [2012a]: Independent Fiscal Institutions in the EU Member States, https:// ec.europa.eu/info/business-economy-euro/indicators-statistics/economic-databases/fiscal-governance-eu-member-states/independent-fiscal-institutions_en

European Commision (2012b): Fiscal frameworks across Member States: Commission Services' Country Fiches From the 2011 EPC Peer Review. DG-ECFIN Occasional Papers, 91.

European Commission, SWD (2012) 317 final.

European Commission, 2013/C 217/10).

European Commission, SWD (2014) 418 final.

European Competitiveness Report 2014.

European Commision (2018): Autumn 2018 Economic Forecast. European Commission, https://ec.europa. eu/info/business-economy-euro/economic-performance-and-forecasts/economic-forecasts/autumn2018-economic-forecast-sustained-less-dynamic-growth-amid-high-uncertainty_en.

France: www.hcfp.fr/.

Germany: www.stabilitaetsrat.de/DE/Home/home_node.html

Hungary: www.parlament.hu/kt.

IMD World Competitiveness Yearbook, 2000-2016.

IMF (2011): Hungary: Staff Report for the 2010 Article IV Consultation and Proposal for Post-Program, www.imf.org/external/pubs/ft/scr/2011/cr1135.pdf.

Ireland: www.fiscalcouncil.ie.

Netherlands: www.cpb.nl.

OECD (2007, 2012, 2014, 2016): Economic Survey of Hungary.

United Kingdom: http://budgetresponsibility.org.uk/. 